\title{
Unravelling the Yamaji imaginings of Alexander Morton and Daisy Bates
}

Robin Barrington

In the late nineteenth and early twentieth centuries, Alexander Morton and Daisy Bates deployed the photograph as a privileged evidentiary anthropological document. Their photographic representations of Yamaji from Western Australia circulated within a transnational network of discourses and practices involving anthropologists, police, pastoralists and journalists, and served to cement views of Yamaji as racially homogeneous, primitive and uncivilised. This article explores the histories behind these photographs and their polysemy to challenge some of the scientific and popular 'truths' disseminated about their Yamaji subjects. It discusses how Yamaji ${ }^{1}$ as figures of Aboriginalist discourse were represented in the work of two influential public figures, Alexander Morton and Daisy Bates, and through their interactions within scientific and colonial networks of power.

Alexander Morton was a collector and the Curator and later Director of the Tasmanian Museum and Art Gallery (hereafter TMAG) from 1884 to $1907 .^{2}$ Daisy Bates was an ethnographer, Travelling Protector of Aborigines, journalist and novelist. ${ }^{3}$ The history of photography in Western Australia and elsewhere has been closely aligned with that of anthropology and colonialism, and these links are clearly discernible in the discursive, disciplinary and representational practices of both Morton and Bates. ${ }^{4}$ Yamaji as constructs of anthropological and other forms of Aboriginalist discourse weave in and out of Western Australian government documents, colonial records, popular cultural texts, newspapers,

Peoples and individuals (male and female) from the Yamaji language groups of Western Australia.

Also see Huxley 2008. Morton was Secretary of the Royal Society of Tasmania during this period.

Also see Bates 1936a, 1938; De Vries 2008; Reece 1987, 2007, 2008.

Also see Edwards 1992, 2001; Pinney 1992, 2011; Pinney and Peterson 2003; Poignant 1992; Lydon 2005 on the links between photography, anthropology and colonialism. 
scientific publications and photographs. In contrast, for their descendants, including this author, photographs of Aboriginal ancestors, even those taken as anthropological specimens, are now being reinterpreted and regarded as precious visual records of personal family histories. ${ }^{5}$ The direct, fixed and haunting gaze of the many Aboriginal subjects in these photographs, project an inherent and enduring strength and dignity that cannot mask the trauma of invasion and colonisation. These photographs framed by colonial and scientific practices require particular ethical deliberations, and in some circumstances, carry injunctions on their re-presentation to family, community and the public. ${ }^{6}$ While for some spectators, the incorrect naming and captions attributed to the Aboriginal subjects discussed below may appear arcane or trivial, for Aboriginal descendants who have no other photographic record it is a vital issue, as these photographs represent a longed-for opportunity to connect with a past that colonial violence has disrupted.

Photographs of Yamaji were taken by Alexander Morton whilst he was on a collecting visit to Western Australia on behalf of the Western Australian Museum and the TMAG from August to October 1897. Two Yamaji in the photographs were named 'Billy' and 'George a Nannine Native'. The colonial archive reveals that George's Yamaji name was Jaal, and much of his story unfolds against the backdrop of the devastating impacts of colonisation in the Murchison district of Western Australia during the late nineteenth and early twentieth centuries. Jaal was a prominent figure and lawman (known as King George of Meekatharra) and this article traces him, and a number of other Yamaji who surrounded him, through the colonial archive. The events and stories recorded about Jaal as an object of scientific enquiry, ethnographic informant and outlaw, also intersected with the lives of prominent colonial figures other than Morton and Bates, such as Henry Walsh and Constable (later Police Inspector) G. J. McDonald, and anthropologists Radcliffe-Brown, Baldwin Spencer, and E. B. Tylor.

This article explores the histories of the photographs and their polysemic aspects to challenge some of the scientific and popular 'truths' disseminated about four Yamaji encountered in the historical records: Jaal, Jinguru, Booreeangoo and 'Murchison Woman'. It asks what they represent to different groups, both in the past and the present, as instantiations of the various forms of disciplining and violence - from epistemic and discursive violence to the physical violence of dispossession and incarceration in hospitals and prisons - inflicted on

5 Edwards 2001; Lydon 2005; see Aird in Lydon 2014; Poignant 2004; Braithwaite et al. 2011.

6 Permissions and endorsements from Jaal's kin, and members of the Wajarri community working group guide my re-presentation of photographs here. 
Aboriginal subjects. ${ }^{7}$ These questions will be explored through a critical analysis of the relevant colonial documents and anthropological photographs of Yamaji taken by Morton and those held in the Bates collection. ${ }^{8}$

\section{A grave undertaking: The collecting expedition of Alexander Morton to the Western Colony in 1897}

Morton's collecting expedition in 1897 occurred amidst political moves to establish Western Australia and Tasmania as distinct entities among the Australian colonies, expressed in part by the expansion of their museum and art collections. It was a time of nationalistic fervour for a 'white' Australia, backed by the Australian Natives Association in preparation for Federation in 1901. ${ }^{9}$ It was in Hobart, at a meeting of the Federal Council in January 1897, that Morton met with Western Australian representatives Mr J. W. Hackett and Sir James Lee-Steere, who invited him to undertake a collecting visit on behalf of the museums in their respective colonies. ${ }^{10}$

The Murchison area of Western Australia, a rich goldfield and pastoral district, was undergoing rapid colonial expansion at this time. This inevitably led to escalating tensions and violence between Yamaji and settlers, in particular with pastoralists, miners and the police. In 1892, Resident Magistrate and owner of Mileura station Henry Walsh warned of the increasing threat posed by the 'natives ... who will shortly make the country unbearable and dangerous to live in', and called for the reintroduction of flogging. ${ }^{11}$ In April the same year, following pressure from the powerful pastoral lobby, the 'Whipping of Aboriginal Native Offenders' was reintroduced as legal punishment. ${ }^{12}$ During Morton's visit to Western Australia from August until November 1897, the deaths of Aboriginal station workers from a brutal flogging took place near Marble Bar. The shocking nature of the case received international attention, and became

\footnotetext{
$7 \quad$ I refer to Jaal as Yamaji because of his connection to that country and its people. Jaal also called himself a Wanmula but spent most of his life with his Wajarri Yamaji family on his mother's country near Meekatharra. 8 The Morton photographs have been made available to Jaal's kin through this research and they consent to their publication. It was not possible to obtain permissions for the photographs in the Bates collection as will be explained below. Further research, and perhaps this publication, may enable the subjects in the photographs to be identified and reclaimed by their descendants and kin.

9 Griffiths 1996; Blackton 1958: 37-46.

10 'A visiting scientist', The Inquirer and Commercial News, 1 October 1897; Morton 1898a.

11 Walsh 1892.

12 An Act to Amend the Aboriginal Offenders Act 1883 and to Authorise the Whipping of Aboriginal Native Offenders 1892 (WA).
} 
known as 'the Bendhu atrocities'. ${ }^{13}$ Morton became a willing participant in the ongoing controversy over the cruelty and slavery inflicted on Yamaji, and as a scientist contributed his own 'expert' views in support of the pastoralists. ${ }^{14}$

Before commencing the expedition, Morton had written from Hobart to Bernard Woodward, Curator of the Western Australian Museum, and, in a tone of some urgency, suggested, 'my idea is we should pay particular attention to the [e]thnology of your country as every year the natives are getting lesser and lesser' ${ }^{15}$ Morton's collecting activities occurred in a context in which Aboriginal bodies and artefacts were seen as increasingly valuable to an international market, and were procured by questionable means. The Royal Society of Tasmania and Trustees of the Tasmanian Museum and Art Gallery met to farewell Morton and to wish him every success in the collection of 'general natural history, geological and ethnological specimens' ${ }^{16}$ At this meeting the Speaker jokingly commented that he was inclined to think that if Mr Morton had to revise the Ten Commandments, he would modify the one "Thou shalt not steal" by adding "except for the Tasmanian Museum and Art Gallery"'. Morton's genial reply to the jovial banter about recent art acquisitions for the TMAG was quoted, and indicates that neither he nor at least some of his peers saw the reference to stealing and evading customs as more than a laughing matter. ${ }^{17}$ This disregard by Morton in relation to methods of acquiring art is no less apparent in his desecration of Yamaji graves and his treatment of Aboriginal remains. At this time, Aboriginal skulls were still considered as crucial material evidence for anthropological and evolutionary theories and, despite public protests, the plunder of Aboriginal graves for scientific purposes took place out of public view. ${ }^{18}$ Morton's assistant, John Tunney, had been taking instructions from Woodward on the collection of Aboriginal skulls and skeletons before Morton's visit to Western Australia. ${ }^{19}$ For Morton, who was to later send the skeletal remains of Truganina to Baldwin Spencer in Melbourne for articulation, the interests of science and the TMAG collection were paramount. ${ }^{20}$ His actions regarding Truganina's skeleton, and the exhumation of graves on the Murchison for Yamaji remains, suggest that

\footnotetext{
13 See Wills-Johnson 2014; 'Bendhu atrocities', The West Australian, 8 January 1898: 6.

14 Morton 1898b.

15 Morton 1897.

16 'Royal Society of Tasmania: Departure of Mr. Alexander Morton for West Australia', The Mercury (Hobart), 4 August 1897.

17 'Departure of Mr Alexander Morton', The Mercury (Hobart), 4 August 1897.

18 See Gough 2014. Lanne's body was dismembered by two doctors found to be acting on behalf of The Royal Society of Tasmania and the Royal College of Surgeons in London. Also see Turnbull 2008; Daley 2014; Chadwick 2008; McDonald 2007; Prinsep 1905, State Records Office of Western Australia (SROWA) Con 255 , item 425/1905.

19 See Chadwick 2008. Due to cultural sensitivities, the author is not reproducing these images here.

20 Letter from Alexander Morton to Spencer, 31 March 1904, Museum Victoria Archives. Widely held public disgust and opposition in relation to these scientific practices were known to Morton. In December 1878, the Colonial Secretary gave in to relentless demands from the Royal Society of Tasmania to exhume Truganina's remains for scientific study on the condition that they were to be kept from public view.
} 
Morton pressed the boundaries between zealous collecting and stealing in his ambitions to expand the TMAG's collections. In 1904, Morton put Truganina's skeleton on display at the TMAG despite her express wish that her remains did not suffer the same shocking fate as those of William Lanne, whose skull was removed after his death, and a substitute put in its place. ${ }^{21}$

\section{The search for origins: Salvaging Jaal as anthropological specimen}

Morton's collecting visit to Western Australia and his photographs of Jaal contributed to an internationally based 'salvage' anthropology that became a matter of some urgency, especially amongst the scientific circles of Europe. ${ }^{22}$ For Morton, Tasmanian Aboriginal peoples were already extinct by then, and the Murchison area presented a 'terra incognita' for his collecting activities. From Nannine, Morton wrote to Woodward:

... I think I have got some valuable data - the stone implements they use for making their spears and the women's fighting sticks are identical the same as the Tasmanian, ... the shape is so similar that if the Tasmanian and the one from this district were placed side by side it would be impossible to tell the difference ... The discovery of these two matters I think should be of very great interest from an ethnological point. ${ }^{23}$

It was this 'discovery' by Morton that linked Jaal to the international debates on race, evolutionism, human origins and migrations by metropolitan British scholars. This interest in the connection between Tasmanian Aboriginal and Yamaji stone axes was also shared by E. B. Tylor at Oxford. ${ }^{24}$ With a letter to Tylor, Morton sent images of Jaal and his family as photographic evidence of racial type and wrote:

Dear Dr Tyl[o]r, Intended in my last to send you one or two photos of the natives I met in the Murchison district West Australia last year. The photos I now send are some I took myself during my trip. They will give you some idea of the natives

\footnotetext{
21 K. O. S. 1947; McDonald 2007; Morton 1900 AIATSIS PMS 5018; ‘Death of the last Aboriginal Tasmanian male', Launceston Examiner, 27 March 1869; Frost 2001. The pronunciation and spelling of Truganina's name varies and continues to be debated.

22 Salvage anthropology was driven by a perception that Indigenous Australians represented a living relic of the early stages of mankind and were rapidly disappearing, either by 'dying out' or 'contamination' from the effects of the 'civilising' mission. See Edwards 2001; Pinney 2011; McGregor 1997.

23 Morton 1897.

24 Morton had previously sent a collection of Tasmanian stone implements to Tylor at Oxford in 1894. See Tylor 1894.
} 
that have the stone implements similar to those used by the late Tasmanian Aboriginals. The photos are natives some 650 to 700 miles from Perth. Trusting they may be of some slight interest to you. Yours sincerely Alex Morton. ${ }^{25}$

Bates and Henry Balfour, the curator of the Pitt Rivers Museum at Oxford also contributed to this discussion on the ethnological and racial similarities between Tasmanian Aboriginal peoples and Yamaji. ${ }^{26}$ Bates claimed that the facial characteristics of Truganina, the last Tasmanian native woman, have their counterpart in some of the Western Australian natives' ${ }^{27}$ As an anthropological specimen of 'authentic' racial type, Jaal was represented as an embodiment of the primitive savage; to be anything less was of little scientific value to remote anthropological 'experts'. Morton's photographs of Jaal and his family were sent to other influential figures in British anthropology, such as Alfred Cort Haddon, to be interpreted within a discursive network of anthropologists speculating on scientific theories of race.

\section{The reframing of Jaal as Big George: The king, cannibal and outlaw}

While Jaal as 'Big George' remains a relatively unknown figure today, there are several indications that he exercised a kind of fascination over colonial society in Western Australia. Jaal was born near Lake Way around 1870 and first enters the historical record as a prisoner who was sent to Rottnest Island in 1891 for sheep stealing. Soon after his second arrest at Belele near Meekatharra in 1895 for alleged murder and cannibalism, he made a daring escape from police chains with the assistance of his wife. ${ }^{28}$ Following a month of evading the police, Jaal was recaptured and marched in chains to Geraldton, where he spent a month awaiting a trial with five of his kinsmen. Jaal and his co-accused were found not guilty and released to make their own way back to the Murchison. It was this well-publicised case that established Jaal's reputation as 'Big George a reputed Cannibal'. ${ }^{29}$ By the late 1890s, Jaal's increasing conflict with colonial laws ensured that his reputation as 'Big George' the 'outlaw' and 'cannibal' was well known throughout the Murchison district at the time of Morton's visit. The titles of 'Big' and 'King' indicate the high status attributed to Jaal by a colonial society that recognised his influence over Yamaji from the Meekatharra

25 Alexander Morton to E.B. Tyl[o]r Esq., Pitt Rivers Museum Photographic Collection 1998.249.39.3 [LM 3/2/2009].

26 Bates 1912: 48, NLA MS365/1-3; see discussion section of Tylor 1900: 260.

27 Bates 1912: 30, NLA MS365/1-3.

28 Dolan and Breen 1895, Mt Gould Police Station Reports, SROWA Con 430, Item 1895/152.

29 'Cannibalism on the Murchison', The Daily News, 15 January 1895. 
and Lake Way districts. ${ }^{30}$ The titles 'King of the Meekatharra natives' and 'mobbarn man - possessed of much magic' was bestowed upon him through the writings of Daisy Bates, and in a mock 'obituary' that described him as 'King of His Tribe' following his death in 1915. ${ }^{31}$ Jaal operated between two systems of law and the 'chaining' of Yamaji prisoners was still part of police procedure during Morton's visit, one that would continue well into the twentieth century. The Morton photograph (Figure 1) illustrates this brutal practice, and although no other details exist, the subject fourth from the left is possibly that of Jaal.

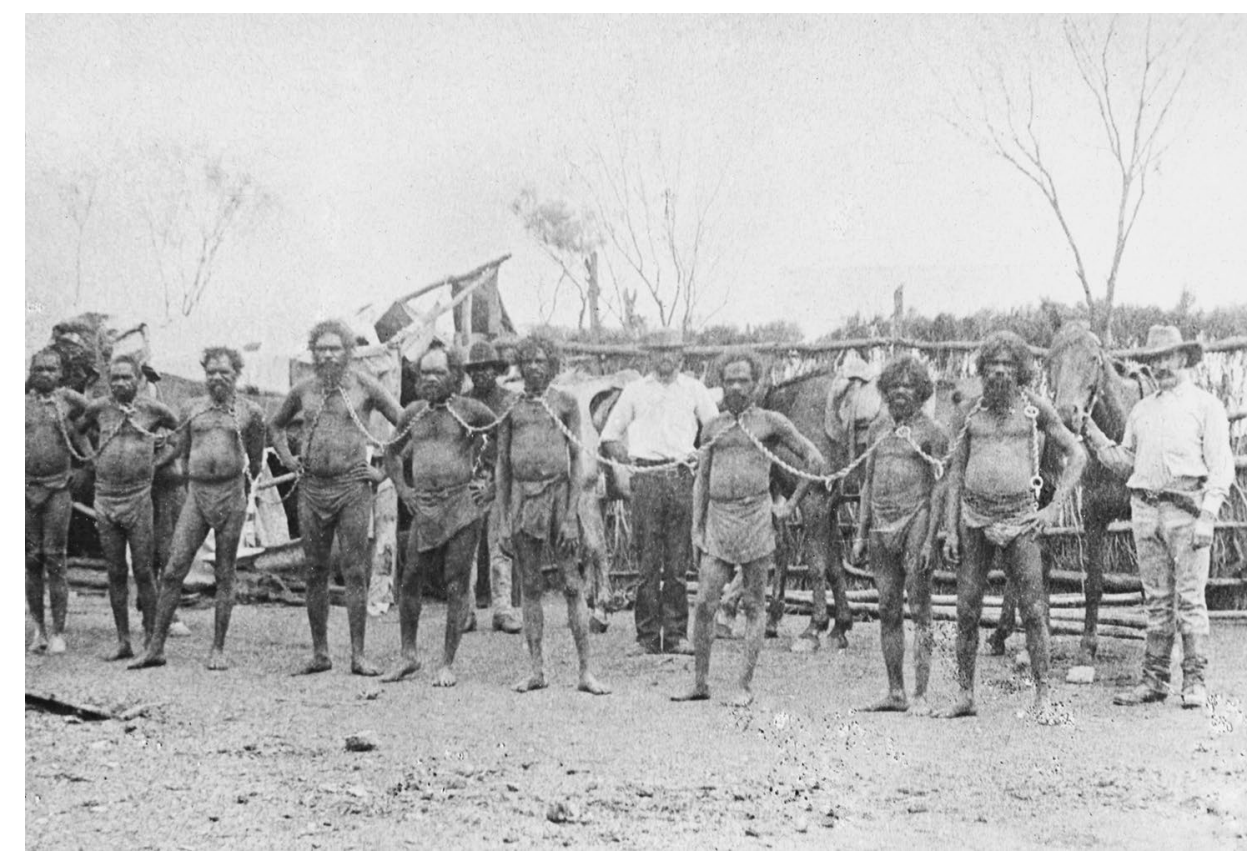

Figure 1: 'Chain Gang Western Australia', photographer Alexander Morton, 1897; prepared by J. W. Beattie.

Source: Courtesy of the Tasmanian Museum and Art Gallery, Q1986.8.138.

The recent incidents of violence and murder of both settlers and Yamaji in the Murchison, and elsewhere in the north-west, made the first encounter between Jaal and Morton a cautious one. In his lantern slide presentation to the Royal Society of Tasmania in June 1898, Morton expressed gratitude for the 'fortunate' presence of the police, noting 'I was enabled to make a more extensive examination than I could have done if I had been alone'. ${ }^{32}$ An armed

30 The WA government's practice of giving titles of king or governor to Yamaji men of influence had been discontinued before Jaal's time as a senior lawman and so he would have acquired this title by reputation.

31 Sandstone Police Occurrence books, March 1915, SROWA Con 1186, Item 5; 'King of his tribe', Meekatharra Miner, 27 February 1915; Bates 1911.

32 Morton 1898a. 
police presence and tobacco were used to persuade Jaal and all members of his family, including children, to disrobe for the camera (see Figure 4). Although there may have been some degree of collaboration, the gun, black tracker and Corporal Tyler captured in the images point to the unequal power relationships that underpinned the ethnological and photographic encounters at Jaal's Nannine camp. ${ }^{33}$

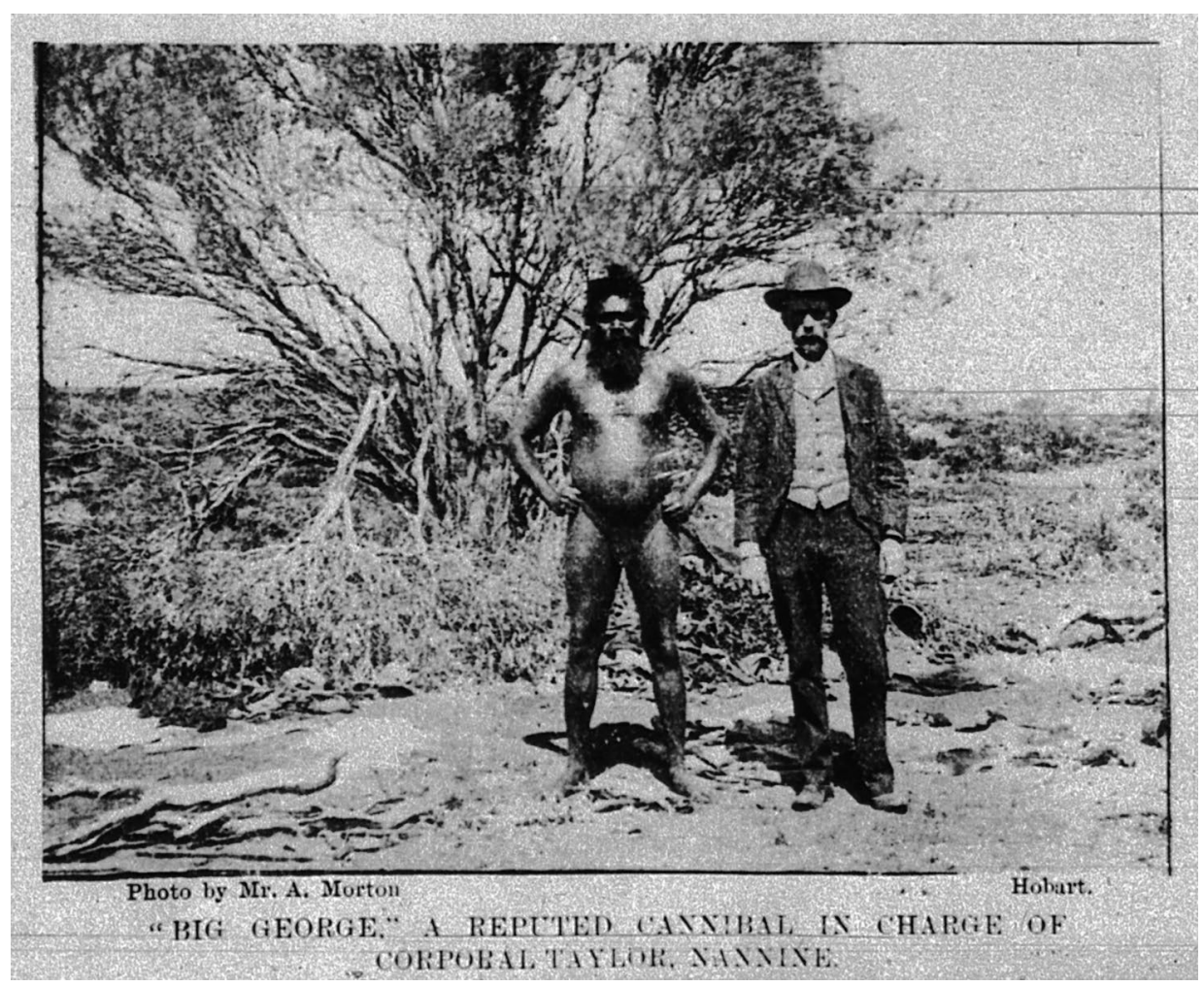

Figure 2: 'Big George a Reputed Cannibal in Charge of Corporal Taylor [Tyler]' in 'Big George', The Western Mail, 24 December 1897.

Source: Available at the State Library of Western Australia on microfilm and at Trove, trove.nla.gov.au/newspaper. 


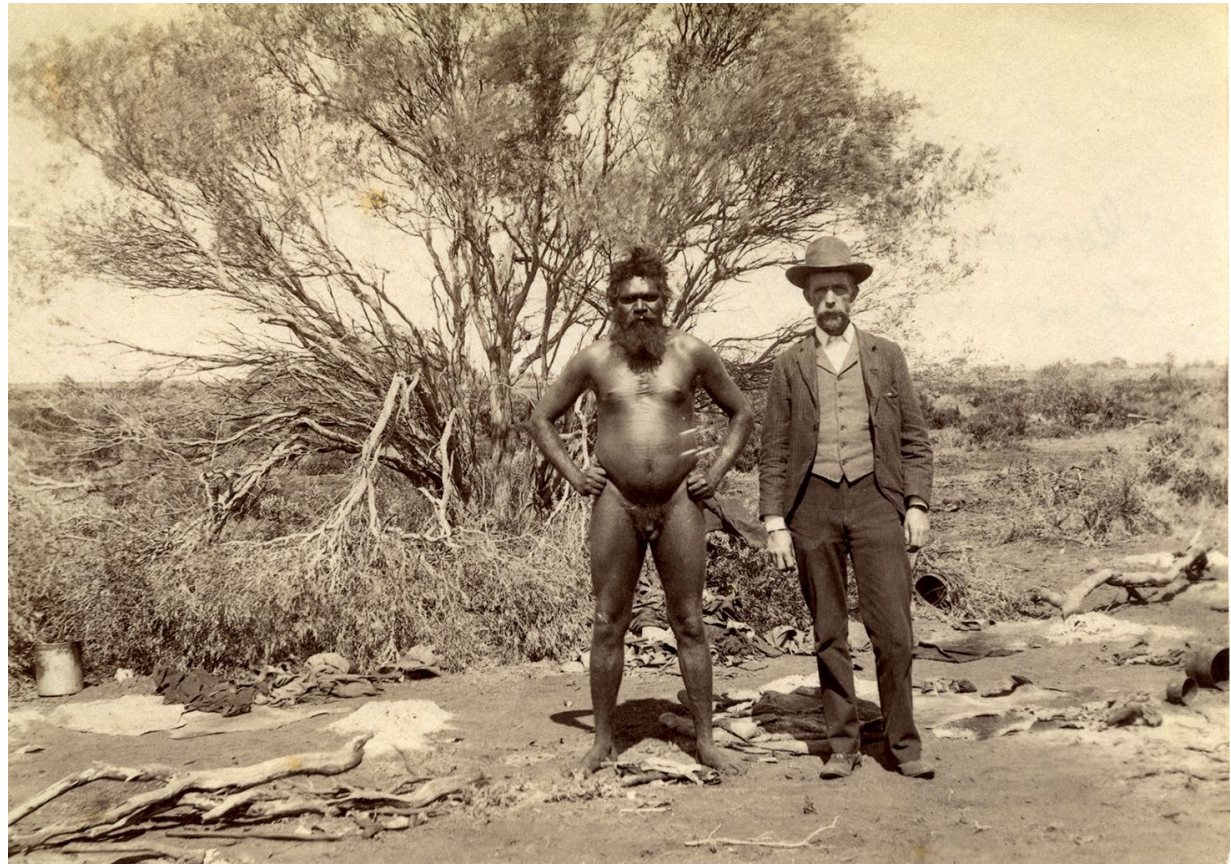

Figure 3: 'George a Nannine Native', photographer Alexander Morton, September 1897.

Source: Courtesy of the Western Australian Museum.

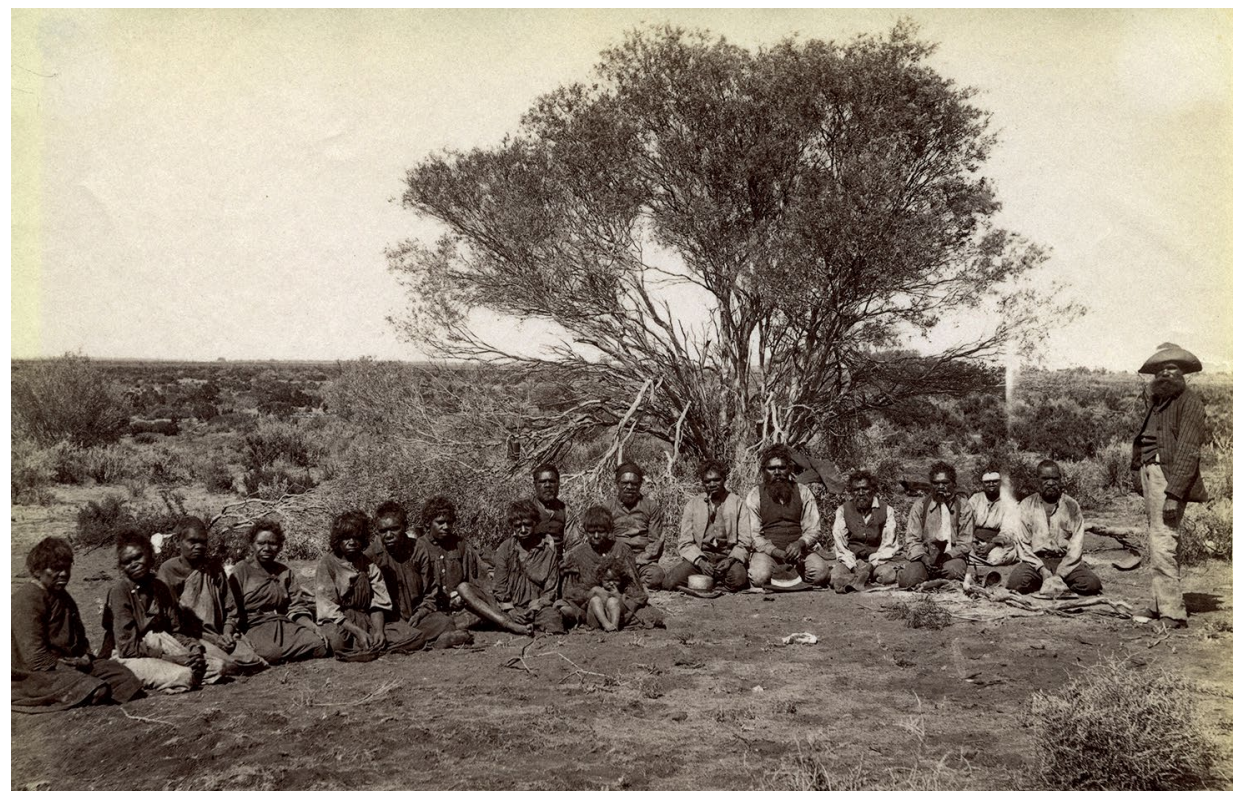

Figure 4: 'Nannine Natives with Tracker', photographer Alexander Morton. Source: Courtesy of the Western Australian Museum. 
The compelling photograph of Jaal and Corporal Tyler (see Figures 2 and 3) circulated in newspapers for popular consumption six months prior to Morton's presentation to the Royal Society of Tasmania in 1898. The polysemic nature of photographs, allowing them to be interpreted in a range of contexts, is evident in the way that the Morton images operated seamlessly between popular culture and salvage anthropology over time. At the Royal Society meeting and in the earlier newspaper article, Jaal was described as a 'cannibal' and a 'fine specimen' of anthropological race type. Jaal's physical size was the object of Morton's fascination, and Corporal Tyler was positioned within the frame as a prop for raciological comparisons (see Figures 2 and 3). Jaal's body was projected from a lantern slide prepared by well-known Tasmanian photographer J. W. Beattie for the scientific scrutiny of Royal Society members. These comparisons between Jaal and Corporal Tyler, the latter described as 'a fine type of the Caucasian', were articulated in the earlier illustrated newspaper story of Jaal as 'Big George' in 1897. In this popular narrative, Jaal was constructed through visual and written text as a 'fine specimen' of 'native type', the 'cannibal', 'captive', and the dangerous outlaw in a spectacle of colonial power represented by Corporal Tyler. ${ }^{34}$ The authority of the photograph in disseminating representations of Aboriginal bodies as colonial spectacle was already familiar through their display at international colonial exhibitions and commercial travelling shows and circuses. ${ }^{35}$ As suggested by Ballard, the power of raciology 'as an institutionalised system of knowledge has derived from its capacity to inform, and be informed by, both popular understandings of difference and the machinery of state and colonial administration' ${ }^{36}$ The photograph has played a significant role in these institutional systems of knowledge and power, and the ways in which Yamaji were represented within them.

\section{Anthropological photographs as popular discourse}

The publication of Morton's anthropological images of Jaal and other Yamaji in newspapers coincided with news coverage of the Bendhu atrocities. The atrocities near Bendhu station initially involved charges of brutality inflicted upon seven Aboriginal station workers, three of whom were flogged

34 Morton 1898; 'Big George', The Western Mail, 24 December 1897.

35 Poignant 2004.

36 Ballard 2008: 340. 
to death for 'absconding from duty' ${ }^{37}$ Public outrage led to the charges being upgraded to wilful murder and the court proceedings surrounding the accused, the Anderson brothers, were reported widely in Australia and a 'full report of the trial ... reached England'. ${ }^{38}$ Morton publicly refuted these claims of brutality and his photograph of Wajarri people working on Henry Walsh's Mileura station was used to illustrate his testimony that:

The group of station natives may be taken as typical. Mr Morton found the station natives a well fed, healthy and contented race. He felt sure, from his own personal observation, that such events as the Bendhu atrocities were so far from the normal that no blame could be broadcast because of them. ${ }^{39}$

Morton continued to downplay the cruelties some months later, and in his 'Notes' read to the Royal Society of Tasmania he stated, 'As to the treatment and conditions of the natives on the various stations I visited, I can confidently say that it would be impossible for them to be treated better than they are on the Upper Murchison' ${ }^{40}$
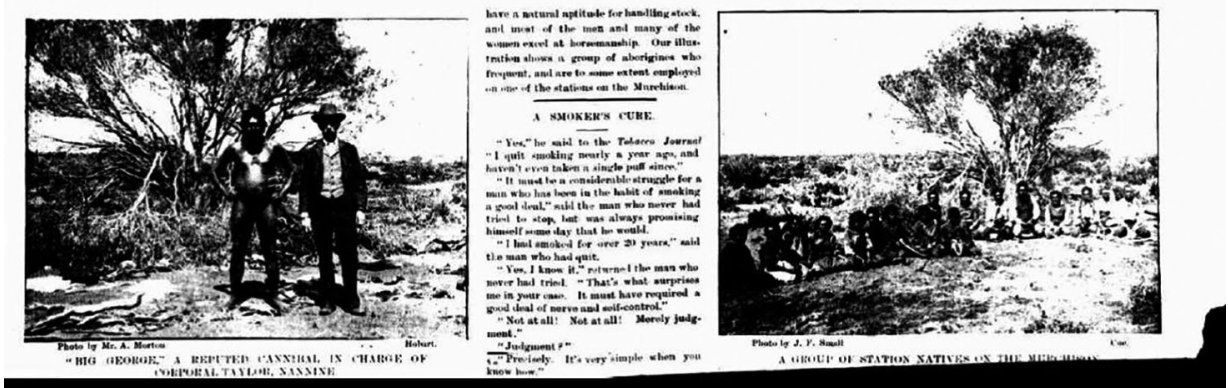

Figure 5: Jaal as the 'reputed Cannibal Big George' and as one of a 'Group of Station Natives on the Murchison' in The Western Mail, 24 December 1897.

Source: Available at the State Library of Western Australia on microfilm and at Trove, trove.nla.gov.au/newspaper.

\footnotetext{
37 The Anderson brothers Ernest and Alexander, managers of Bendhu station, were initially charged with the unlawful brutality of seven Yamaji station workers in a local court at Bamboo Creek near Marble Bar, fined £2 and issued with a warning. 'The Bendhu manslaughter case: Allegations against Mr Warden Oslund', 11 March 1898, Western Mail: 10. Following public criticisms, the police subsequently upgraded the charge to wilful murder. The Anderson brothers were tried for murder but found guilty on the lesser charge of manslaughter. 'The Bendhu atrocities', The Argus, 24 December 1897: 5. According to the West Australian, Ernest Anderson was the first white man to be found guilty of manslaughter and sentenced to life imprisonment for the murder of an Aboriginal person under the legal system of self-government in Western Australia. 'Bendhu atrocities', The West Australian, 8 January 1898: 6. Alexander died in Fremantle gaol of typhoid fever before the trial, Ernest was 'liberated' on a 'ticket of leave' on 10 February 1903, having served six years of his life sentence. 'News and notes', The Western Mail, Thursday 12 May 1904: 4. Also see Wills-Johnson 2014.

38 'Bendhu case', The Inquirer \& Commercial News (Perth), 28 January 1898; 'How we treat the blacks', The Inquirer \& Commercial News (Perth), 21 January 1898: 8.

39 Morton 1898b: 26.

40 Morton recommended 'the gentlemen' who assisted him on his collecting visit to the Murchison and they were 'unanimously elected' as corresponding members of the Royal Society of Tasmania, Royal Society of Tasmania 1898.
} 

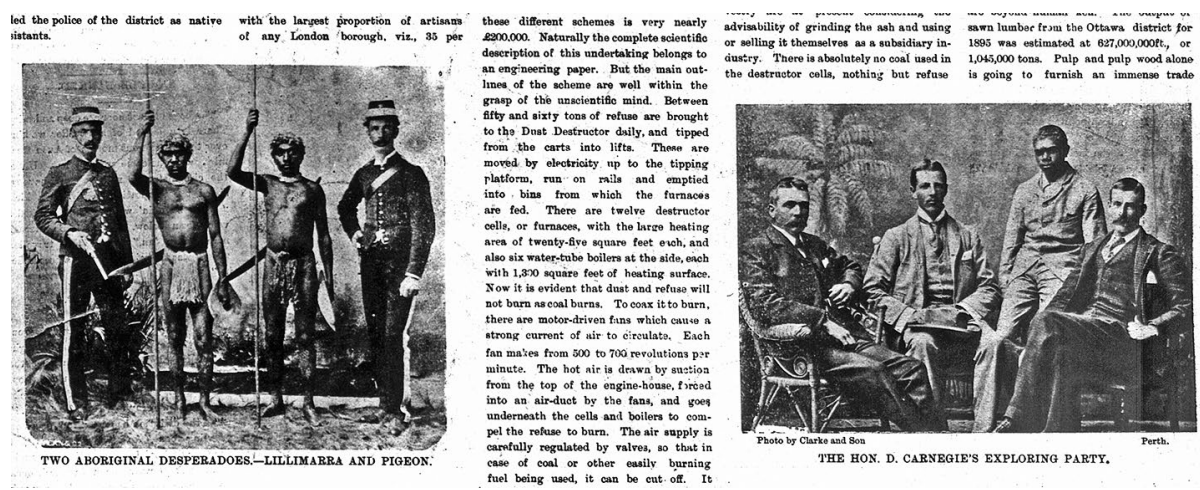

Figure 6: 'Two Aboriginal Desperadoes - Pigeon [Jandamarra] and Lillimarra [Ellemarra]' and Hon. D. Carnegie's Exploring Party in The Western Mail, 15 October 1897.

Source: Available at the State Library of Western Australia on microfilm and at Trove, trove.nla.gov.au/newspaper.

Photographs of Aboriginal people were an important aspect of Western Australian newspapers since they were first used by the Western Mail in July 1897. Juxtapositions of 'civilised' and 'uncivilised' Yamaji appeared in illustrated news features to promote the 'successes' of colonisation and its 'civilising mission'. Images similar to those taken by Morton were published amidst news reports on the Bendhu atrocities (see Figures 5 and 6). These bifurcated photographic representations reproduced a narrative of colonial power where Jaal appears at the same time as one of a group of 'Station Natives on the Murchison' and as 'Big George the Reputed Cannibal' (see Figure 5). Jaal as 'Big George' became a kind of receptacle for continuing colonial anxieties about 'violent and savage natives' wanted for murder and cattle killing. These included an attempted murder of a white settler in 1901, and several alleged murders of 'white men' in 1905 referred to as 'the Peak Hill Murders' that were in fact linked to other Yamaji. The reports in the Murchison Advocate, Western Mail and Murchison Chronicler of 'wholesale murders of white men', Yamaji uprisings and 'poison corroborees' reflected settler panic and hysteria that echoed the earlier stories of Jaal's cannibalism. ${ }^{41}$ These events in Jaal's life paralleled the continuing mistreatment of Yamaji that would lead to yet further controls by the state with calls from settlers for the 'natives' to be disarmed. ${ }^{42}$ By 1902, photographs of Aboriginal people were a regular feature in the Chief Protector of Aborigines' annual reports. To quell ongoing public criticism, the Chief Protector of Aborigines issued a directive to publish 'condensed' versions

41 Growden 1905: 12-13; 'Wholesale murders by Peak Hill Blacks', Murchison Advocate, June 1905; 'Natives and whites: Aboriginal murders in the north: Sleeping men tomahawked and speared bodies frightfully mutilated: Cannibalism hinted at', The Western Mail, 1 July 1905: 18.

42 Aborigines Act 1905 (WA). 
of Travelling Inspector's annual reports in local newspapers with photographs, 'shewing [sic] how well clothed and comfortable the natives appear at present to $\mathrm{be}^{\prime} .{ }^{43}$

The colonial myths attached to Jaal continued to circulate long after his death in the figure of Carringoora a Yamaji man, also known as Big Charlie, who became conflated with 'Big George' ${ }^{44}$ The 1935 illustrated article (see Figure 7) also coincided with investigations into allegations regarding the mistreatment of Aboriginal station workers in the north-west. What became known as the 'Aboriginal Question' was raised yet again in the 1935 Mosley Report, and its recommendations were written into the Aborigines Amendment Act 1936. ${ }^{45}$ In the news story of 'Big George alias Carringoora' (see Figure 7), Jaal again became the threatening 'notorious native' type in a nostalgic return to the days of 'native depredations' and police heroes at the colonial frontier. ${ }^{46}$ Jaal and Carringoora were powerful Yamaji men in constant conflict with colonial law, and these popular narratives elided an undeclared war and the bloody violence inflicted on Yamaji, despite the condemnations expressed by the 'minority reportage' of whistle blowers and humanitarians. ${ }^{47}$ The voices of these lonely protestors were drowned out by the politically powerful pastoralist lobby and they were publicly humiliated, financially ruined and subjected to self-imposed exile. ${ }^{48}$ In April 1899, soon after the Bendhu case, Police Constable O. Ritchie complained about the mistreatment of Yamaji station workers at Berringarra and the lack of justice afforded them by local magistrate Henry Walsh, owner of Mileura station. ${ }^{49}$ Police Constable Ritchie was suspended from duty pending an investigation that found his allegations were 'exaggerated'. He stated that he was forced to resign from the police force on 14 August 1899, and he died within a year of the inquiry which had exonerated all those accused. ${ }^{50}$

\footnotetext{
43 Western Australia. Aborigines Department 1903.

44 When Morton was photographing Jaal at Nannine in 1897, Carringoora was imprisoned on Rottnest Island for five years for the attempted murder of Constable Phelan. Shortly after Carringoora's release in May 1901, he speared another settler in the stomach and was shot dead by Constable Gordon at Manfred station in the Murchison on 10 June 1901. Julitha Walsh from Mileura station republished this story. Walsh 1950. Big George as Carringoora was also featured in Heydon 1990.

45 H. D. Mosley, 1935.

46 'Carringoora alias Big George: Exciting Murchison episodes of 30 years ago', The Sunday Times, 15 December 1935.

47 Also see Bottoms 2013.

48 Paisley 2012; Reynolds 1982, 1972; Advocate 1899; 'Gribble vs The West Australian: The trial and verdict', The West Australian, 7 June and 28 June 1887; Western Australia. Aborigines Department 1902.

49 Ritchie 1899b.

50 Ritchie 1899a; also see under Beringarra in the 1901 Chief Protector of Aborigines' annual report, Travelling Inspector G. S. Olivey 1901: 20.
} 


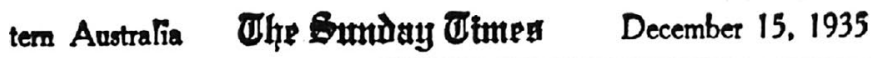

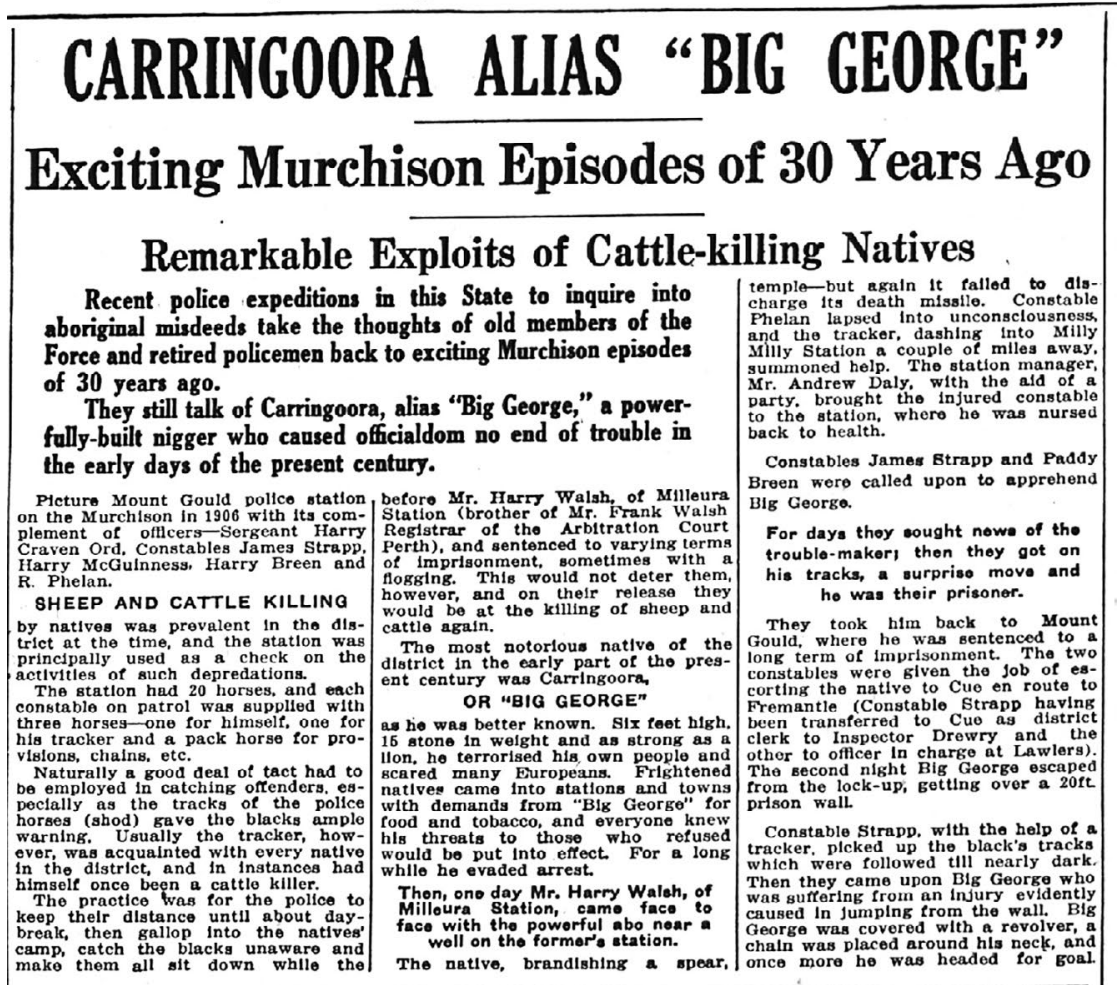

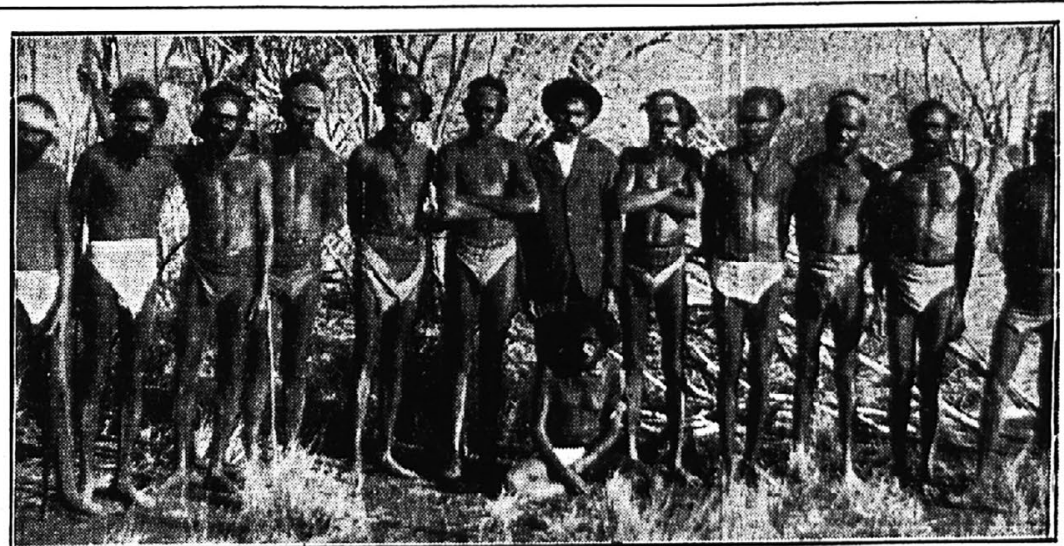

\section{A Group of Murchison Aboriginals}

tracker pointed out the offenders and throatened to k111 the wtation owner, Thue onded the activit placed them on the chaln provided. Who carrled only a stock whlp. Mr notort Thls chaln was about 25 ft. long, light Walsh swung hos horso toward, the conetable strapp, by the way, lo and very strong (Bomething like a natlve. knocked the spear from hls
trace chain), whlle about every, 3ft.
hand and prevented bim from regain-

Figure 7: Carringoora Alias 'Big George' in The Sunday Times, 15 December 1935.

Source: Available at the State Library of Western Australia on microfilm and at Trove, trove.nla.gov.au/newspaper. 
The encounter between Jaal and Morton at Nannine on the Murchison took place amidst these colonial tensions and violence that became exacerbated by recent discoveries of gold there. Jaal was as a central figure in these conflicts and was represented in popular narratives as 'civilised', 'cannibal' and 'outlaw' and, at the same time, as an informant and 'specimen' of international scientific interest. This was a significant role that Jaal would continue to play for Bates in her ethnography for the Western Australian government and the Cambridge University Expedition during 1910-1911.

\section{Daisy Bates: Jaal my brother, and other Yamaji imaginings}

Daisy Bates was an eccentric and enigmatic figure who claimed to be a friend of and an expert on Aboriginal people, and her life has been the subject of a number of biographies. ${ }^{51}$ Bates' lifetime spent amongst 'her Aborigines' began at a time of increasing interest in Australian Aboriginal peoples by international scientists and colonial administrators. She arrived in Western Australia from England in August 1899, following the allegations of mistreatment towards Aboriginal people published in London newspapers referred to earlier. ${ }^{52}$ In her 'special report' for the London Times - which she claims to have written following her 'investigations' through the north-west in late 1899 - she found 'not one charge of cruelty'. ${ }^{53}$ As with an earlier visit to Tasmania, this journey had apparently sparked her interest in the 'Aborigines' and Bates soon established herself within a discursive network of scientists and government officials.

Before her fieldwork for the Western Australian government began in 1904, Bates wrote to many people, including Alexander Morton and Baldwin Spencer, requesting 'scientific' information on Aboriginal people. ${ }^{54}$ The extent of this network is indicated in a letter Bates wrote to Harry Princep, the Chief Protector of Aborigines, on 16 June 1905:

Professor Baldwin Spencer, to whom I had written concerning some 'class divisions' in his latest ethnological work on the Aborigines which somewhat resembled those obtaining in certain parts of the Nor' West of this State, is looking up the subject most enthusiastically and promises me his kindly

\footnotetext{
51 Reece 2007; De Vries 2008; Salter 1971; Hill 1973.

52 These reports by Malcolmson referred to the Bendhu case and Bates also refuted Malcolmson's subsequent 1904 protest letter to the London Times regarding ongoing cruelty and slavery in the north-west. See also Wills-Johnson 2014; Reece 2007.

53 'My natives and I: Life story of Daisy M. Bates', The Advertiser, January and February 1936.

54 On 3 May 1904, Daisy Bates accepted a position offered by Colonial Secretary's Office (CSO) to collect 'native vocabularies and information of customs and habits'.
} 
assistance ... Dr Delaney [Bishop of Hobart] has kindly put me in communication with Mr Morton FRGS [Fellow of the Royal Geographical Society] one of Tasmania's chief scientists. ${ }^{55}$

To Bates, Jaal represented the embodiment of the 'authentic native'. She referred to him in a scientific paper and he was also one of the many Aboriginal people she characterised in her newspaper articles and books. ${ }^{56}$ Jaal was a significant informant for Bates' ethnographical work that included the Cambridge Expedition to Western Australia with A. R. Radcliffe-Brown and E. L. Grant Watson in 1910-11..$^{57}$ The majority of this work was carried out at the Lock Hospitals on Bernier and Dorre Islands, where Aboriginal people suspected of having venereal disease were isolated for treatment. The traumatic conditions experienced by Jaal and other Yamaji, their illness and isolation far from their families and country are unimaginable. The horrors of this medical experiment have been only hinted at so far. ${ }^{58}$ Jaal was incarcerated on Bernier Island on 26 January 1911, and we can discern just how ill he was from Bates who noted, 'Jaal was too wasted from venereal and operations to speak' ${ }^{59}$ As well as surgery, his treatment during his eight months of incarceration may well have included the toxic experimental drug Salvarsan which was used up until May $1911 .^{60}$

From October 1910 until June 1911, Bates carried out dual roles as government attaché to the Cambridge Expedition and as a Travelling Protector of Aborigines directed 'to look into the Native problem' ${ }^{61}$ Bates reported regularly to the Chief Protector of Aborigines, and arranged for 'half-caste' children to be removed to government-supported institutions. From this time, Bates published intriguing stories about Jaal and her relationship with him, claiming him as 'her brother ... being of the same class and generation'. In this story, Bates described Jaal as overbearing and masterful, with a 'cold, cruel, selfish nature that overrides every native law in pursuit of its own ends and desires'. ${ }^{62}$ Her narratives juxtapose Jaal's fearsome masculinity against claims of her own superior magical powers stating:

55 Daisy Bates to Chief Protector of Aborigines, Harry Prinsep, 16 June 1905, in Composite File, CSO: 1904-1912 SROWA Con 1023.

56 Bates 1911, 1912, 1913, 1936b, 1938; Bates 1936c; see also Papers of Daisy Bates, NLA MS365.

57 Born Alfred Reginald Brown, he changed his surname by deed poll to Radcliffe-Brown.

58 Lock Hospitals were medical prisons modelled on a British system set up for women. Most Aboriginal people including Jaal were sent to Bernier and Dorre Islands suspected of syphilis and were later diagnosed with granuloma. See also Bates 1938; Jebb 1984; Grant Watson 1910-11; Grant Watson 1946; Stingemore 2010; Papers of Daisy Bates NLA MS365/71/10; Mulvaney 1989.

59 Papers of Daisy Bates, NLA MS365/55/52.

60 See Stingemore 2010.

61 H. H. Brodribb for Chief Protector of Aborigines to Daisy M. Bates, 10 October 1910, in Composite File, CSO: 1904-1912 SROWA Con 1023.

62 Bates 1911. 
he [Jaal] pays me the compliment of acknowledging both to myself and to his friends that my magic is not only more powerful than his, but that when I am in his vicinity I absorb all his magic, leaving him like any ordinary [Y]amaji (black fellow) which is satisfactory from my point of view. ${ }^{63}$

Through such popular narratives, Bates publicised her professed influence and authority over Jaal and other Yamaji in order to create her own persona, and establish her status and reputation in the eyes of the scientific world, with popular audiences and even royalty. ${ }^{64}$ Bates' laments for Aboriginal people as a 'dying race' litter her writings and genealogies, either through direct references or through inscriptions such as 'last of his tribe' or as 'N.C.' (No Children). There are no photographs of Jaal in her collection, however, a photograph of Jaal's brother-in-law Jinguru, another significant informant of Daisy Bates, remains in her collection. ${ }^{65}$
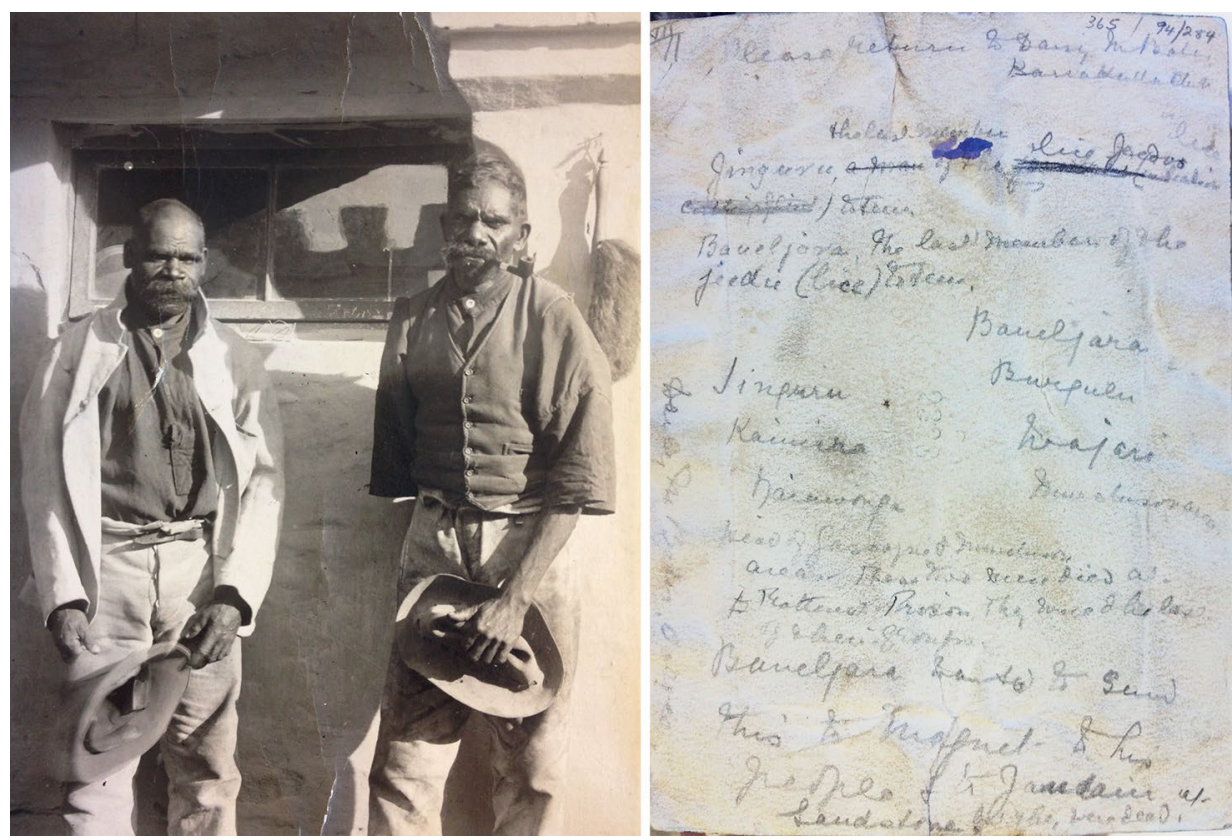

Figure 8: Baueljarra and Jinguru at Rottnest Island Prison: Daisy Bates Collection MS365/Box 40-49 (front and reverse).

Source: Courtesy of the National Library of Australia, Canberra.

63 Bates 1911.

64 Bates' ethnography was used as 'preferred' evidence in Yamaji Native Title claims. See Badimia judgement by Barker in CG (Deceased) on behalf of the Badimia People $v$ State of Western Australia [2015] FCA 204.

65 Bates claimed that at least half of her photographic collection went missing in the offices of the Adelaide Advertiser in 1936. 
On the reverse side of the photograph said to be of Jinguru and a Badimia man named Baueljarra (see Figure 8), Bates wrote, 'these two men died at Rottnest Prison ... and were the last of their groups' ${ }^{6}{ }^{66}$ In The Passing of the Aborigines: A Lifetime Spent among the Natives of Australia, she also described how Jinguru died while she was with him in the gaol cell on Rottnest in 1912, and seeing his grave 'added to the many hundreds on the island', and asserted it was one of her 'saddest memories'. ${ }^{67}$ Bates' touching account of Jinguru's 'death' is in fact a fantasy, and one of her familiar narratives of ministering to 'a dying race'. Baueljarra's fate is unknown, but Jinguru, far from dying in Bates' arms, lived to petition the British King through an interpreter a number of times before he was eventually released from Rottnest in February 1922. Constable G. McDonald and the Chief Protector of Aborigines, A. O. Neville, stipulated on Jinguru's release that he could not return to his country, and he was condemned to serve the rest of his sentence at the Moore River Settlement. ${ }^{68}$ However, in 1924 he escaped back to his wife in the Murchison and, according to a local historian, died there sometime around $1936 .{ }^{69}$

As Travelling Protector, Bates claimed that she played a direct role in Jaal's capture, as a suspected syphilitic, at Sandstone by Corporal Grey in October 1910. ${ }^{70}$ As with Morton's visit, the Cambridge Expedition was provided with police assistance, this time from Bates' good friend, Constable G. J. McDonald who was stationed at Sandstone. He recorded his own stories about Jaal as 'Big George' in the Western Mail under the pseudonym 'Suter Abis' during the 1930s, later combining them into a memoir, as Bates did with her series. ${ }^{71}$ According to Bates, it was an impending police raid to capture Jaal's brotherin-law Jinguru that led to Radcliffe-Brown's decision to relocate his Cambridge Expedition to the Lock Hospitals on Bernier and Dorre Island..$^{72}$ Interestingly, and probably unknown to Radcliffe-Brown, it was Bates who claimed to have provided the police with ethnographical information on Jinguru's country, language group and family genealogies that resulted in his arrest at Wiluna for a 'tribal' murder and his imprisonment on Rottnest Island. ${ }^{73}$

\footnotetext{
66 Papers of Daisy Bates, NLA MS 365/94-96.

67 Bates 1938: 118.

68 McDonald and Neville 1915-1921, SROWA Con 752, item 1915/2671.

69 Heydon 1990

70 Bates describes her role in the capture of 'natives' at Sandstone by Constable (Corporal) Grey in her 1936 newspaper series 'My Natives and I'. Bates provided a list of 'natives' to Corporal Grey that included Jaal. See letter from Daisy Bates to Chief Protector of Aborigines, 31 October 1910, in Composite File, CSO: 1904-1912, SROWA Con 1023; Papers of Daisy Bates, NLA MS365/71/15.

71 G. J. C. McDonald 1996.

72 Daisy Bates to Chief Protector of Aborigines, 31 October 1910, in Composite File, CSO: 1904-1912 SROWA Con 1023.

73 Daisy Bates to Chief Protector of Aborigines, 1 December 1910, in Composite File, CSO: 1904-1912 SROWA Con 1023.
} 
Jaal and other Yamaji were transported in chains to Carnarvon, bound for the Lock Hospital on Bernier Island (for men) and Dorre Islands (for women), and this had tragic consequences for their families. Daisy Bates met up with Jaal in the Carnarvon camp on 23 January 1911, where she assisted in loading him aboard the Olive, bound for Bernier Island. While Jaal was sent to Bernier Island, his young 'half-caste' wife Mailgurdi was sent to New Norcia mission. ${ }^{74}$ It was also at this time that Jaal's brother-in-law Jinguru was sent to Rottnest Island for life with hard labour, and his aunty and mother-in-law were sent to Dorre Island. ${ }^{75}$ The Lock Hospital and other prisons were sites of trauma, punishment, discipline and surveillance for Yamaji that became an important space for ethnographic investigations and medical experiments.

Bates typified the close links between anthropology and colonialism, and her regular reports to the Chief Protector of Aborigines from Bernier Island were a testimony to her significant role in the governmentality of Yamaji. ${ }^{76}$ Early ethnographic material, including that of Bates, is used today as 'preferred' evidence in Native Title cases in Western Australia. ${ }^{77}$ Bates claimed that she secured Jaal's release from Bernier Island, but he remained there until his discharge as 'cured' of granuloma, in September $1911 .^{78} \mathrm{Jaal}$ was killed four years later, reportedly from a lightning strike and was buried by his kin on the rabbitproof fence near Barrambie not far from Sandstone. ${ }^{79}$ Jaal's young brother-in-law Hugh (Mailgurdi's brother) kept his experiences of these horrendous times to himself throughout his life. Since Hugh's death, his daughter Jan has continued searching to find out more about her Yamaji family, despite the difficulties of having to come to terms with the dark and violent past that he kept from his wife and children. Morton's photographs of Jan's Yamaji family are now being reinterpreted as valuable visual registers of long-missing kin, despite their original intent as anthropological records.

\footnotetext{
74 See Nannine Police Occurrence books, 20 October 1910, at SROWA. CSO: 1904-1912 SROWA Con 1023: 46. 75 Gaols Department, SROWA Con 968, Item 526/1911. NLA MS365/88/53-4; Medical Officer 1911, SROWA Con 652, Item 782/1911.

76 On governmentality see Foucault 1977, 2004, 2008, 2009; Dean 2010.

77 See Barker 2015; Muller 2014.

78 Medical Officer to Chief Protector Aborigines, 'Returns of Patients', June 1911, SROWA Con 652, 1911/782. Also see Stingemore 2010; Jebb 1984

79 'Death of George King of the Meekatharra Natives at Errols', 1915, SROWA Con 1186, Item 5; 'King of his tribe', Meekatharra Miner, 27 February 1915.
} 


\section{'Please return to Daisy Bates': The fabrication of Murchison women}

The haunting portraits of 'Murchison Woman' and 'Booreeangoo' of Yalgoo emerged as shadowy images in microfilm at the State Library of Western Australia. ${ }^{80}$ My grandmother and her mother were born near Yalgoo on the Murchison, and here I thought I had found in these photographs the faces of my ancestors. For a time the photograph of Booreeangoo had 'returned' home, to be cherished and framed by her family and kin. But sadly, as I was to learn, Bates' designations cannot be taken at face value, and again bear out the unreliable nature of colonial and photographic truths. The photograph 'Aboriginal Woman of the Murchison' (see Figures 9 to 11) was published in 1936 as part of Bates' 'My Natives and I' newspaper series and, as with many of her photographs, the back was inscribed with ethnographic information. ${ }^{81}$ When searching online for photographs of Yamaji, I recognised with utter disappointment the photographic figure Bates characterised as a 'Murchison Woman'. Here in digital form though, her name was now 'Minningun' (see Figure 11), a woman from the Macleay River district of New South Wales, some thousands of miles from the Murchison. In 1909, a photograph was used to illustrate a newspaper story written by Bates of Booreeangoo's tragic death and burial ceremony in 1908 (see Figure 12). ${ }^{82}$ Tracing the photograph of Booreeangoo to another photograph captioned 'Coondah Moss Vale Tribe, N.S.W.' (see Figure 13) was less straightforward. The photograph of Coondah from the Kerry and Co. Studios is now part of the Tyrrell Collection held by the Powerhouse Museum in Sydney. Although the photograph is taken at a slightly different angle to that of Booreeangoo, the visual clues, particularly the distinctive scar on her right eyebrow, and Bates' substitution of Minningun for Murchison Woman, strongly suggest that Booreeangoo and Coondah are one and the same person.

The way in which Bates acquired the photographs of Minningun and Coondah is not known, but these types of studio images were readily available for sale to the public as prints prior to 1900 and after 1903 were also printed as postcards. ${ }^{83}$ The photographs of Minningun are amongst a series of 150 images from the Kerry and Co. Studios that are said to have been produced sometime between the 1880s and 1890s. ${ }^{84}$ It is known that a photograph of 'Nerelle princess of Moruya' was also in this same series with 'Minningun', and the image was published

\footnotetext{
80 Papers of Daisy Bates, NLA MS 365/94.

81 Bates 1936c.

82 Bates 1909.

83 Peterson 1985; Millar 1981.

84 Barker 2009. The photographs are estimated as produced between 1880 and 1899; also see Pitt Rivers Museum and State Library of New South Wales online database.
} 
as a composite poster in $1895 .^{85}$ Bates came to Western Australia in 1899, and it is extremely unlikely that she had access to the professional photographic equipment required to produce images such as these. It is more likely that Bates acquired the photograph from Kerry and Co. Studios, who purchased and printed photographs taken by others, and also employed staff photographers. ${ }^{86}$

The international dissemination of photographs of Aboriginal people, including those popular images produced by Kerry and Co. Studios, were of ethnological 'interest', and their use in this context was an accepted practice from at least the 1880s onwards. The full face and profile studio photographs of Minningun conformed to an anthropometric style and, as noted by Edwards, 'if commercially produced images can be said to have an ethnographic intention through the broadly racialised discourses of colonial photographic practice, their absorption into the scientific gave them authority' ${ }^{87}$ Bates' motivations to publish as an authority on Aboriginal peoples, and her handwritten notes on the reverse of the Kerry and Co. Studio photographs can be interpreted as a very specific example of discursive violence through erasure and re-inscription. The Kerry and Co. signature was removed, and in her distinctive handwriting Bates expropriated Minningun as her own 'Murchison Weld Range District / The true Murchison type female', going so far as to locate her country and naming 'Weetamurra' as her 'male type from the same area' (see Figure 9). Weetamurra, a Yamaji from Yalgoo, was also featured photographically as a race type in the 'My Natives and I' series by Bates, and also photographed by C. E. Farr in a group preparing for a staged corroboree in Perth in 1909.

On the front of the photograph of Booreeangoo (see Figure 12), Bates wrote 'please return to Daisy Bates ...' as a means of establishing ownership of the image, and also recorded Booreeangoo's age, country and how she was accidentally burnt to death. Booreeangoo was a well-respected Wajarri Yamaji from Yalgoo who married, worked and raised a family near Mindoola in the Weld Ranges. Bates was present at Booreeangoo's burial ceremony, and also described it in her news article, field journal and typed manuscript. ${ }^{88}$ Bates placed great emphasis on the specificity of ethnography through a lifetime of fieldwork; however, in her use of photographs with ethnographic captions she has demonstrated her shallow essentialist vision, where one 'native' is interchangeable with another. Bates' known views about the racial homogeneity of Aboriginal people were influenced

\footnotetext{
85 Millar 1981: 16.

86 Millar 1981: 27. Kerry and Co. also acquired the Henry King studio collection and some images of the same person have both the King and Kerry studio signatures on them. For other difficulties attributing the photographer to similar images, see Aird 2014.

87 Edwards 2001: 40.

88 Bates 1909
} 
by scholarly debates at the time. ${ }^{89}$ These theorists confirmed Bates' opinion that Aboriginal people were from 'one common stock, since the same distinguishing characteristics are observable in tribes occupying widely separated extremities of the continent' ${ }^{90}$ Her claims as to the physical resemblances between Yamaji women and Truganina, discussed earlier, were typified in the way she used the photographs of Minningun and Coondah to represent Yamaji as race 'type'. ${ }^{11}$
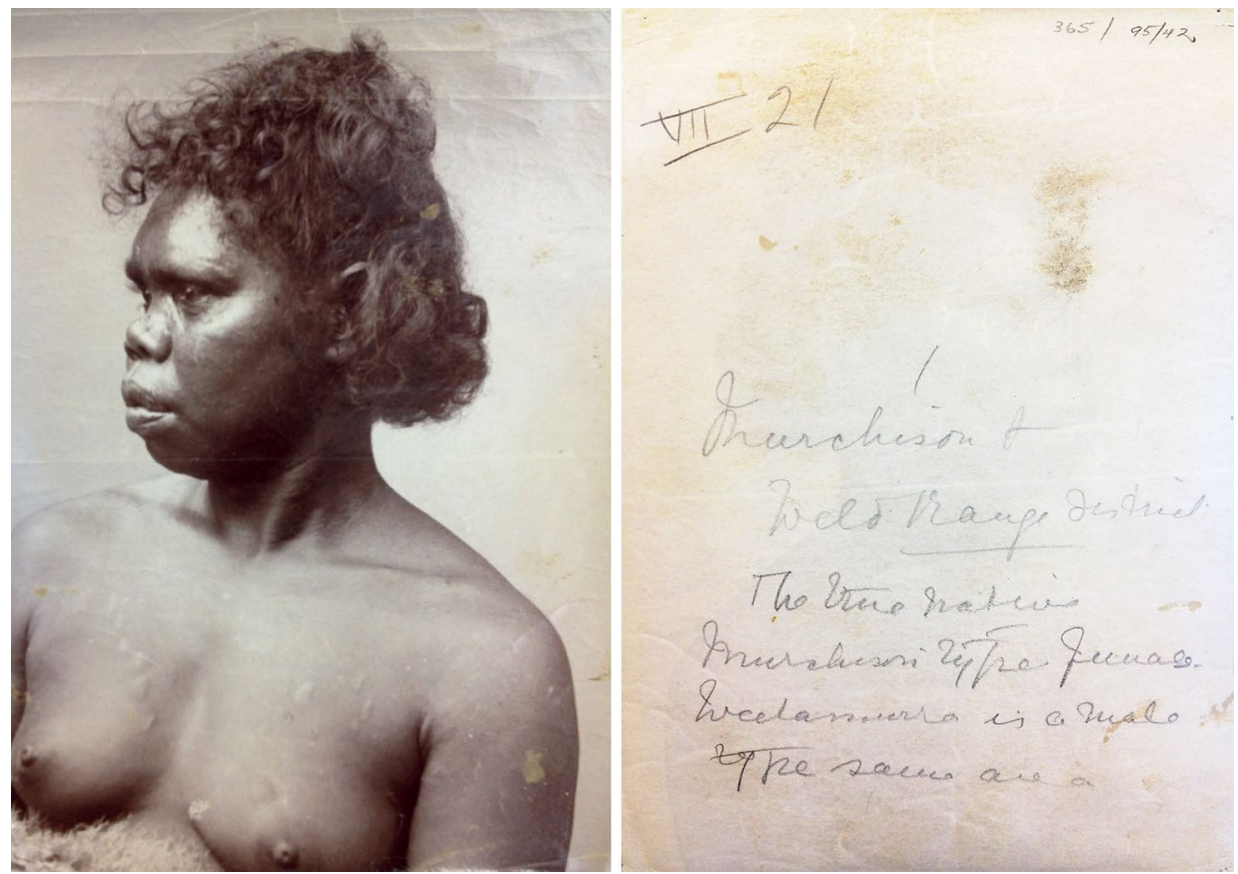

Figure 9: ‘Murchison Woman’, Daisy Bates Collection MS365/94.

Source: Courtesy of the National Library of Australia, Canberra.

89 Bates 1912, NLA MS365, Folio 66.

90 See Bates' unpublished draft Manuscript Chapter on Origins Section 1.1, page 1, accessed from University of Adelaide digitised special collections.

91 'Stock' images to represent race type continue in digital form today. See www.istockphoto.com/ by Getty Images for examples. 
Gien Carrick, in unce of a couisin in ut the purchase of b of 770 well-fed rowsing round the some 40 miles east back vividly to my les of Adam Lindaterson and other ase stirring verses salms of high ad[ knew! Today I of a Hereford cow -washed faces, for 1 them, with elght ix six months, 1,000 ent but some $\mathbf{3}, 000$ ing behind the mob a miles a day, and surpassing the Irish This great mob, number that had he West Kimberleys $s$ duly lifted from

snt $I$ obtained from who was a Maorl was mostly "breed" Just a few decent mass. Sundry drovo engaged, whose le art about equalled - ourselves with the tory and poem, and er and his lieutenand branding, tried is in true stockman mbing into the trees ash, the stockwhips $p$ and hidden in the 5y-whip or less am$f$ sapling and twine

a good English pigih ordinary stirrup; wallaby skin shoes: good British cloth, tout holland; a felt riding gloves, and

A compact hold all ried all necessaries. essible on the dray, he stores for the trip ios. and no mountin uUwil. ${ }^{\text {H }}$ LWLSted ankle moment play, and but the horse had had enough play, and came along to an anthill, from the top of which I mounted and proceeded on the journey.

As we talled along over the Eighty-mile, prodding a sturdy. Little calf or clubbing a day-old weakling, those of us who were

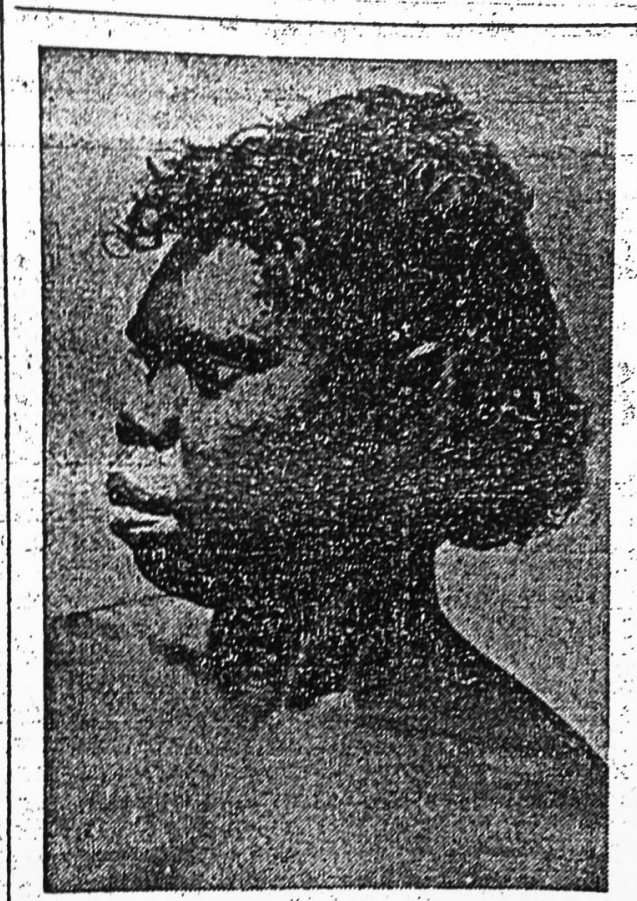

Aboriginal woman of the Murchison.

at the base of the great moving triangle were surprised one morning to see the mob suddenly split in two, leaving a narrow lane along the centre, and along the lane quiletly. walked a Jew pedlar, with his huge pack strapped to his back. Drovers and horses stood like statues as inoses passed through the Red Sea, never once hastering. No one would belleve him if he triled to tell that tale The head drovers were waiting for him-for- human stomai and six happ. and farewell

The tablelar are splendid I able at all tim tableland is level and has 8 laide.

We crossed to the Fortes with excellent 1 now increased after day, we thick mulga and Mitchell $g$ Hull was Peter the homestead. the early days. a horde of ând ammunitio as they well $\mathrm{k}$ for two days his portion of keeping the cr They hurled the but he had lea pons: on the the station.

Our

Our worst st Fill property, 0 in a fenced $p$ had a long al calves reluctan thers half ma distracted with men were dow and guiding th It was dark whe passed through

Relying on th the safety of thi ately unsaddled the cattle brok fence, heading 8 the pools ther cept those too in a twinkling, and calves wer water myself. droving hand, w look efter our drovers heătét.

Figure 10: 'Aboriginal Woman of the Murchison', Daisy Bates in The West Australian, 2 February 1936.

Source: Available at the State Library of Western Australia on microfilm and at Trove, trove.nla.gov.au/newspaper. 


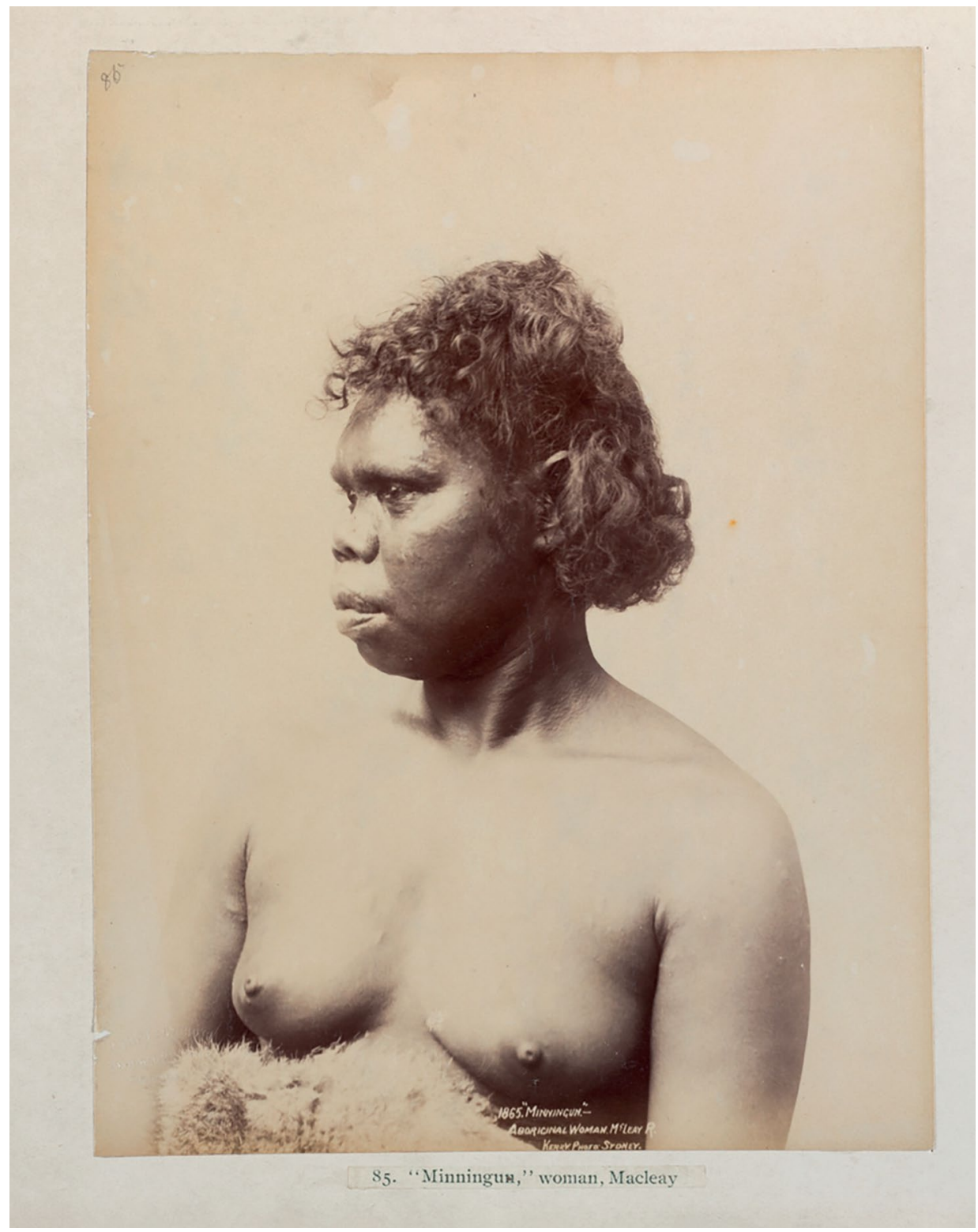

Figure 11: 'Minningun a MacLeay River Woman' from the Kerry Studios. Source: Courtesy State Library of New South Wales and Powerhouse Museum, Sydney. 


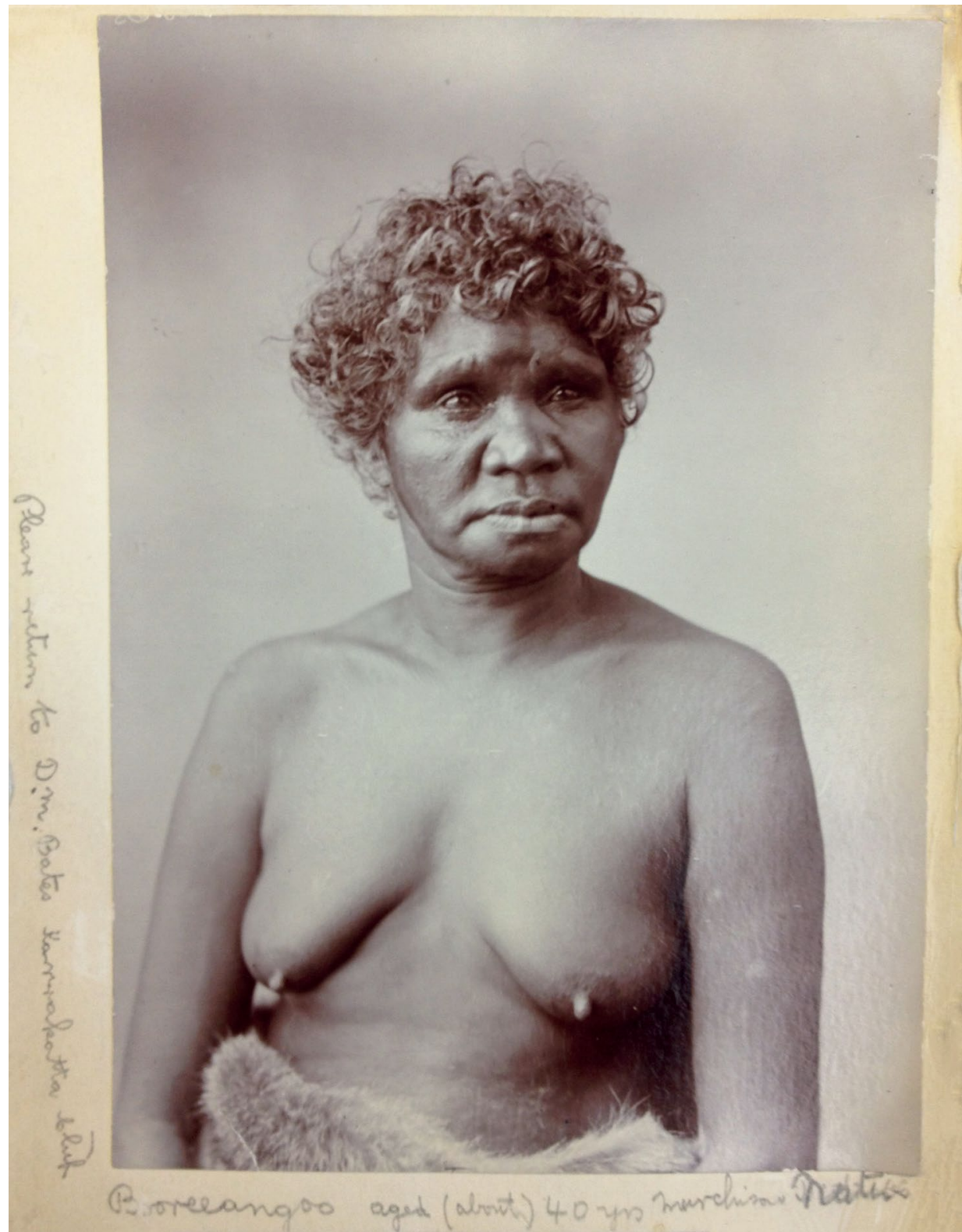

Figure 12a: 'Booreeangoo', Daisy Bates Collection MS365/94.

Source: Courtesy of the National Library of Australia, Canberra. 


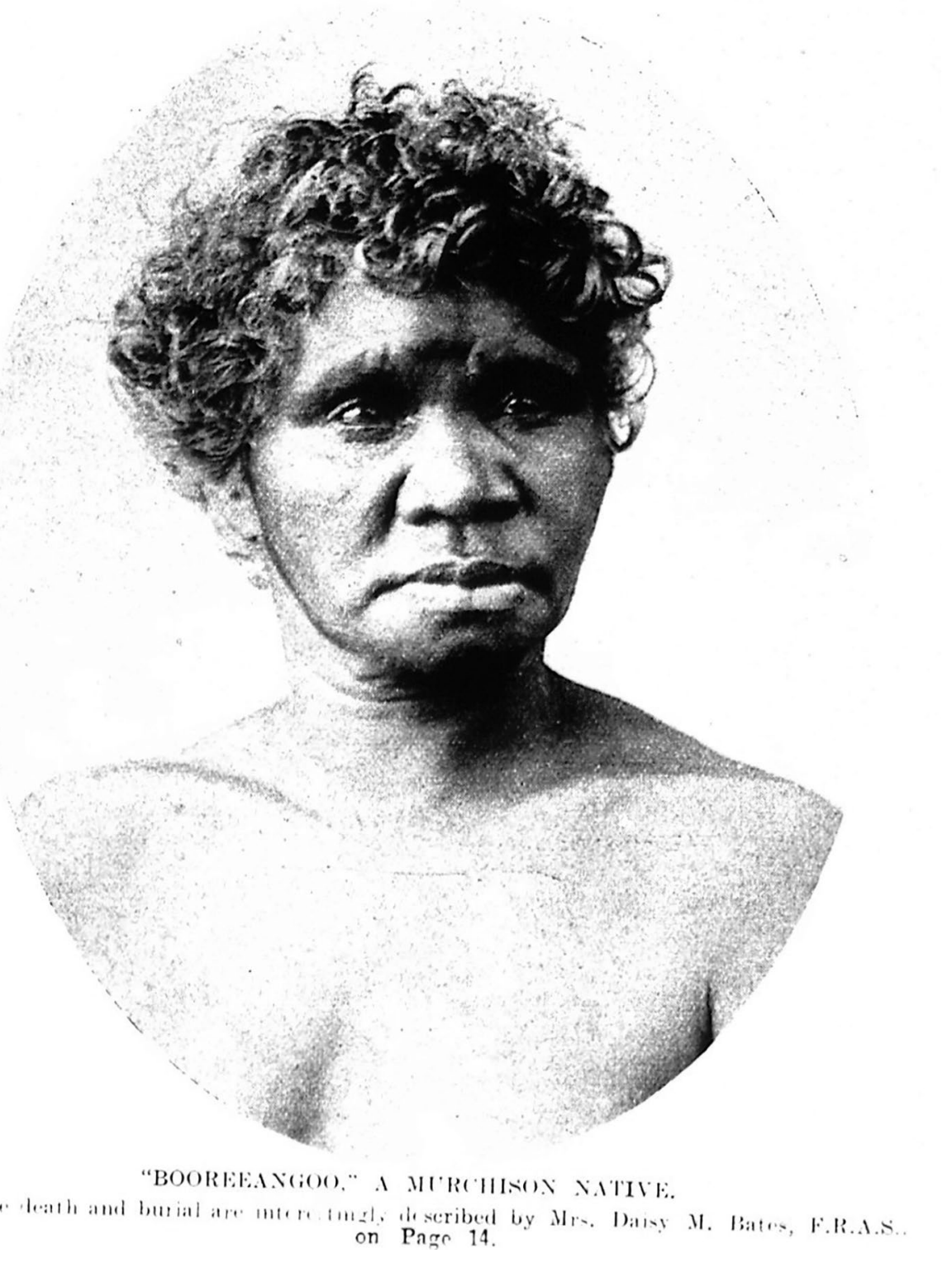

Figure 12b: 'Booreeangoo' in The Western Mail, 4 December 1909. Source: Available at the State Library of Western Australia on microfilm and at Trove, trove.nla.gov.au/newspaper. 


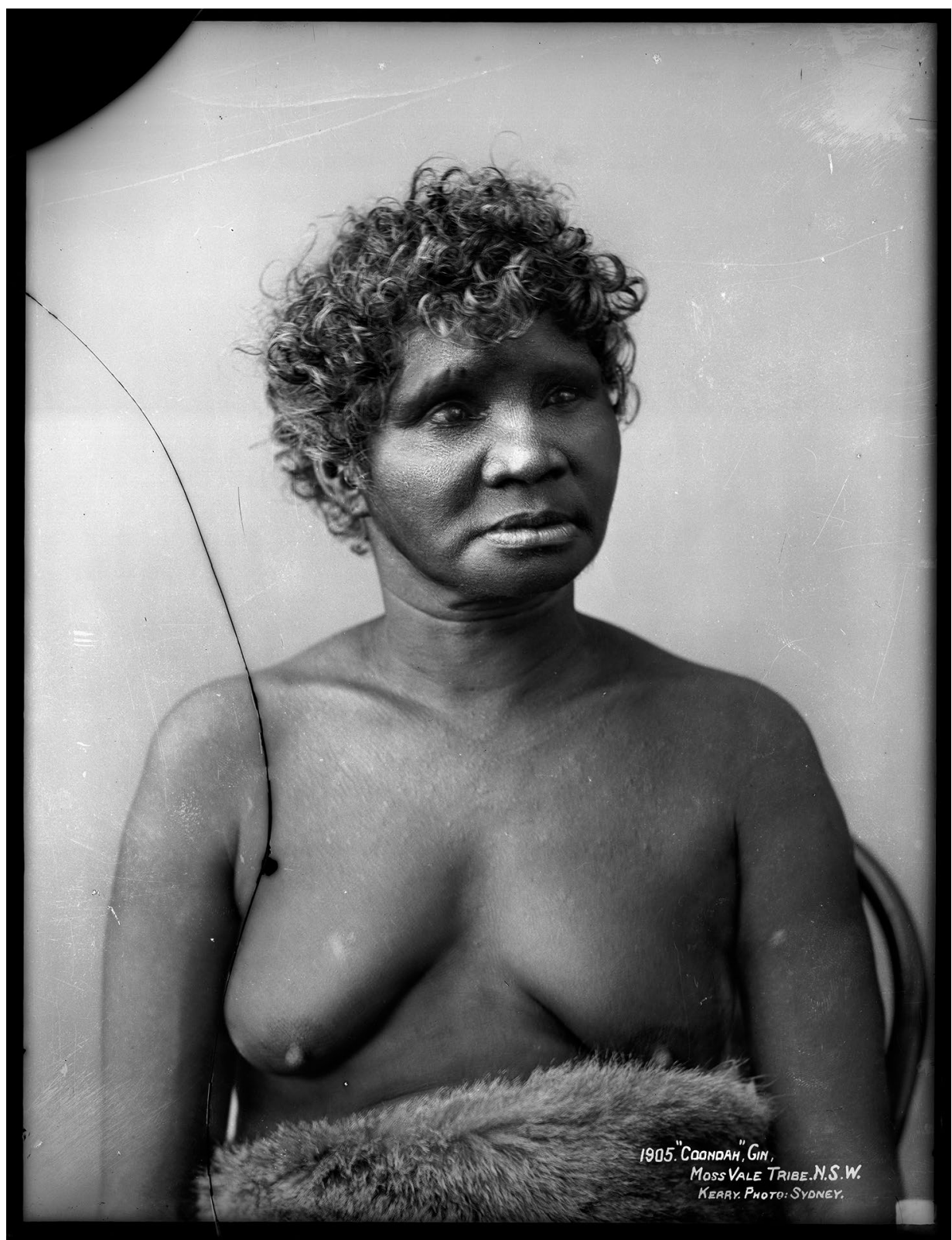

Figure 13: 'Coondah' from Kerry and Co. Studios (possibly taken by Henry King).

Source: Courtesy of the Tyrell Collection at Power House Museum, Sydney. 


\section{Conclusion}

Morton's photographs of Jaal were produced within an anthropological framework and were disseminated within colonial and scientific discursive relationships of power that essentialised Jaal and other Yamaji as the 'authentic' and 'savage' other. The photographs of Yamaji taken by Morton and those in the Bates collection have operated seamlessly as illustrations of scientific and popular racial discourse. The photographic substitution of Minningun and possibly Coondah from New South Wales by Bates to represent Yamaji women from the Murchison, in both popular and ethnographic registers, exposes a more sinister and complex discursive violence of erasure and re-inscription. The particular histories of the photographs of Booreeangoo and Murchison Woman represent a double loss to Yamaji descendants and kin, and for now must be 'returned' to Daisy Bates.

The search for meanings within the labels and histories attached to Jaal and other Yamaji in this article is an interpretive task, but the fragmentary texts in the colonial record can tell us that Jaal, a Yamaji senior lawman and leader of his people, lived in the Murchison and Lake Way districts during the early days of colonisation in Western Australia. These records also register the occurrences of his conflicts with white laws, arrests, incarcerations and finally his death and burial at Barrambie with full ceremony in 1915. These documents trace Jaal's life of violence and surveillance by scientists and government officials, and of his criminalisation and punishment as a prisoner and suspected syphilitic. Early police accounts of Jaal as 'perfectly civilised' were later replaced with the more enduring colonial tropes of 'cannibal' and 'outlaw' that were concomitant with his increasing retaliations for violence and dispossession. What the archive also reveals is the way in which the lives of Alexander Morton and Daisy Bates, and other influential figures, intersected with each other and with Jaal, Jinguru and other Yamaji. As authoritative voices within institutionalised colonial networks of law and science, they constructed representations of Yamaji through an Aboriginalist discourse that would also serve to further their own reputations.

While Jaal and his brother-in-law Jinguru were well-known Yamaji figures of some notoriety during the early period of colonisation in the Murchison, they remain relatively unknown today. Oral histories still exist of Jinguru and Booreeangoo in the memories of their kin, but living memories of Jaal have yet to be found. The identities and stories attached to Jaal, Jinguru and Carringoora were melded into colonial fictions and spectacle that promoted its 'success' and justified the violence inflicted on Yamaji at its frontiers. It is not possible to know the 'real' Yamaji figures of Jaal, Jinguru, Booreeangoo, Baueljarra and Carringoora, because their histories have been transformed and conflated 
with others over time. But it is possible to re-interpret and reposition Yamaji photographic figures within a more complex social and historical context, a network of discursive power relations, and the shared histories of violence, dispossession and colonisation in Western Australia.

\section{References}

\section{Archival sources}

\section{National Library of Australia}

Bates, Daisy 1912, 'The Aborigines: Their homogeneity', Papers of Daisy Bates, NLA MS365, Folio 66.

-1912, 'The native tribes of Western Australia', Papers of Daisy Bates MS365/1-3.

Grant Watson, Elliot L. 1910-11, Letters and Papers, NLA MS4950.

Papers of Daisy Bates, NLA MS365

\section{State Records Office of Western Australia}

Bates, D., Composite File, CSO: 1904-1912 SROWA Con 1023.

'Death of George King of the Meekatharra Natives at Errols', Commissioner of Police. Sandstone Police Occurrence Book, 2 March 1915, SROWA Con 1186, Item 5.

Dolan, A., Police Constable, and HP Police Constable Breen, 1895, 'Murder and Cannibalism', Mt Gould Police Station Reports, SROWA Con 430, Item 1895/152.

McDonald, G. and A. O. Neville, 'A boriginal Native Prisoners: 8467 Jandababby, 8465 Morrie Alias Harry, 8466 Jangarie Alias Charlie, 8469 Georgie Coyle. Petition for Remission of Sentence', Office of the Colonial Secretary/Chief Secretary, SROWA Con 752, Item 1915/2671, 1915-1921.

Medical Officer, Supt. 'Lock Hospitals, Bernier Island: Return of Persons, Etc., Treated in the Lock Hospital at Bernier Island', Dept. Aborigines Fisheries, 1911, SROWA Con 652, Item 782/1911.

Prinsep, Henry 1905, 'Dr Durack, Marble Bar asks if he can retain Aboriginal skeletons for scientific purposes', SROWA Con 255, Item 425/1905. 


\section{The University of Adelaide Library}

Bates, Daisy c. 1936, Jaal - Last native of tribe belonging to Wiluna (Wiluna Goldfields), Daisy Bates Digital Archive, Series 2 Native Testaments of old natives, 15, University of Adelaide Digital Library, Adelaide.

\section{Australian Institute for Aboriginal and Torres Strait Islander Studies Library}

Morton, Alexander 1900, 'Account of the Remains of King Billy: The Last Tasmanian Male Aboriginal', PMS 5018, Australian Institute for Aboriginal and Torres Strait Islander Studies Library, Canberra.

\section{Museum Victoria Archives}

Letter from Alexander Morton to Spencer, 31 March 1904, Museum Victoria Archives, Melbourne.

\section{State Library of Western Australia}

Olivey, G. S. 1899-1901, 'Reports on Stations Visited by the Travelling Inspector of Aborigines from 1st September, 1899 to 30th June, 1901' in Western Australia. Aborigines Department, Annual Report, Wm. Alfred Watson, Government Printer, Perth: 16.

Western Australia. Aborigines Department 1901-1903, Annual Reports, Wm Alfred Watson, Government Printer, Perth.

\section{Newspapers}

Advocate

The Argus

The Daily News

The Sunday Times

The West Australian

The West Australian Sunday Times

The Western Mail

\section{Secondary sources}

Advocate, The Murchison. 'Northern slave owners', reprinted in the West Australian Sunday Times, 9 April 1899: 8. 
Aird, M. 2014, 'Aboriginal people and four early Brisbane photographers', in Calling the Shots: Aboriginal Photographies, Jane Lydon (ed.), Aboriginal Studies Press, Canberra: 133-154.

Ballard, Chris 2008, 'The cultivation of difference in Oceania', in Foreign Bodies: Oceania and the Science of Race 1750-1940, Bronwen Douglas and Chris Ballard (eds), ANU E Press, Canberra: 340.

Barker, Geoff 2009, 'Minningun: Statement of Significance', www.power housemuseum.com/collection/database/?irn=30335, accessed 2015.

Barker, Judge J. 2015, ‘Native Title Claim: The Badimia People V State of Western Australia [2015] Fca 204', Federal Court of Australia (ed.), www.judgments. fedcourt.gov.au/judgments/Judgments/fca/single/2015/2015fca0204 Federal Court of Australia,

Bates, Daisy 1909, 'The death of Booreeangoo: An Aboriginal burial', The Western Mail, 4 December 1909: 14, 26.

-1911, 'My camp in the Murchison bush', The Western Mail, 17 June 1911.

_1912, 'Native decorative art', The Western Mail, 30 March 1912: 14, 27.

-1913, 'Social organisation of some Western Australian tribes', in Fourteenth Meeting of Australasian Association for the Advancement of Science, T. S. Hall (ed.), Australasian Association for the Advancement of Science, Melbourne.

-1936a, 'Chapter V: Sojourn in the Dreamtime', Adelaide Advertiser, 10 January 1936: 22.

-1936b, 'My natives and I: Life story of Daisy M. Bates', The Advertiser, January and February 1936.

-1936c, 'My Natives and I: 3,000 miles in the side-saddle', The West Australian, 5 February 1936.

1938, The Passing of the Aborigines: A Lifetime Spent among the Natives of Australia, Murray, London.

Blackton, Charles S. 1958, 'Australian Nationality and Nativism: The Australian Natives' Association, 1885-1901', The Journal of Modern History 30(1): 37-46.

Bottoms, Timothy 2013, Conspiracy of Silence: Queensland's Frontier KillingTimes, Allen and Unwin, Crows Nest, NSW.

Braithwaite, Sari, Tom Gara and Jane Lydon 2011, 'Rom Moorundie to Buckingham Palace: Images of 'King' Tenberry and his son Warrulan, 184555', Journal of Australian Studies 35(2): 165-184. 
Chadwick, Ross 2008, "Your obedient servant": The John Tunney Collection at the Western Australian Museum', in The Makers and Making of Indigenous Australian Museum Collection, Nicolas Petersen, Lindy Allen and Louise Hamby, (eds), Melbourne University Press, Carlton, Vic: 255-280.

Daley, Paul 2014, 'Restless Indigenous remains', Meanjin 73(1): 1-16.

De Vries, Susanna 2008, Desert Queen: The Many Lives and Loves of Daisy Bates, HarperCollins Publishers, Pymble, NSW.

Dean, Mitchell 2010, Governmentality: Power and Rule in Modern Society, second edition, Sage, London.

De Vries, Susanna 2008, Desert Queen: The Many Lives and Loves of Daisy Bates, HarperCollins Publishers, Pymble, NSW.

Edwards, Elizabeth 1992, Anthropology and Photography 1860-1920, Yale University Press in association with The Royal Anthropological Institute, London.

2001, Raw Histories: Photographs, Anthropology and Museums, Materializing Culture, Berg, Oxford.

Foucault, Michel 1977, Discipline and Punish: Birth of the Prison, Alan Sheridan (trans), Vintage Books, New York.

2004, Society Must Be Defended: Lectures at the College De France 1975-76, David Macey (trans), Penguin Books, London.

2008, The Birth of Biopolitics: Lectures at the Colleg De France, 1978-79, Graham Burchell (trans), Palgrave Macmillan, New York.

2009, Security, Territory, Population: Lectures at the College De France, 1977-1978, Graham Burchell (trans), Picador, New York.

Frost, Lucy 2001, 'Displaying Trugernanna', In Storykeepers, Mary Halligan (ed.), Duffy \& Snellgrove, Sydney.

Gough, Julie 2014, 'Forgotten lives - the first photographs of Tasmanian Aboriginal people', in Calling the Shots: Aboriginal Photographies, Jane Lydon (ed.), Aboriginal Studies Press, Canberra.

Grant Watson, Elliot L. 1946, But to What Purpose: The Autobiography of a Contemporary, The Cresset Press, London.

Griffiths, Tom 1996, Hunters and Collectors: The Antiquarian Imagination in Australia, Cambridge University Press, Cambridge. 
Growden, Police Constable 1905, 'The Native Trouble: Cannibalism in the North West: Search for the Murderers: How Toby and Monkey Were Arrested', The Western Mail, 22 July 1905: 12-13.

Heydon, Philip 1990, Nannine by the Lake, Hesperian Press, Perth.

Hill, Ernestine 1973, Kabbarli: A Personal Memoir of Daisy Bates, Angus and Robinson, Sydney.

Huxley, J. K. 2008, 'Courtier to the powerful and zealous curator for the people: The contribution of Alexander Morton to the Tasmanian Museum and Art Gallery, 1884-1907', Kanunnah 2: 1-34.

Jebb, Mary Anne 1984, 'The Lock Hospitals experiment: Europeans, Aborigines and venereal disease', Studies in Western Australian History 8: 13, 68-86.

K. O. S. 1947, 'Truganini: A broken promise', Advocate, 20 December.

Lydon, Jane (ed.) 2005, Eye Contact: Photographing Indigenous Australians, Duke University Press, Durham.

2014, Calling the Shots, Aboriginal Studies Press, Canberra.

McDonald, G. J. C. 1996, Beyond Boundary Fences, Hesperian Press, Carlisle Western Australia.

McDonald, Helen 2007, 'A scandalous act: Regulating anatomy in a British settler colony, Tasmania 1869', Social History of Medicine 20(1): 39-56.

McGregor, Russell 1997, Imagined Destinies: Aboriginal Australians and the Doomed Race Theory, 1880-1939, Melbourne University Press, Melbourne.

Millar, David P. 1981, Charles Kerry's Federation Australia, David Ell Press, Sydney.

Morton, Alexander 1897, 'Letters from Morton to Bernard Woodward Curator of the Western Australian Museum', Western Australian Museum Library, Perth.

- 1898a, 'Notes on a Visit to West Australia (Read at the Royal Society of Tasmania, on Monday, June 13th 1898', Tasmanian Museum and Art Gallery, Printed at the 'Tasmanian News' Office, Hobart, 1-8.

_-1898b, 'Some Murchison views', The Western Mail, 2 January 1898: 26.

Mosley, H. D. 1935, Report of the Commissioner appointed to Investigate, Report, and Advise upon matters in relation to the Condition and Treatment of Aborigines, Fred W. M. Simpson Government Printer, Perth. 
Muller, Craig 2014, "The "allurements of the European presence": Examining explanations of Wongatha behaviour in the Northern Goldfields of Western Australia', Aboriginal History 38: 59-87.

Mulvaney, D John 1989, Encounters in Place: Outsiders and Aboriginal Australians 1606-1985, University of Queensland Press, St Lucia.

Paisley, Fiona 2012, The Lone Protestor: A M Fernando in Australia and Europe, Aboriginal Studies Press, Canberra.

Peterson, Nicolas 1985, 'The popular image', in Seeing the First Australians, Ian Donaldson and Tamsin Donaldson (eds), George Allen \& Unwin, Sydney.

Pinney, Christopher 1992, 'The parallel histories of anthropology and photography', in Anthropology and Photography, Elizabeth Edwards (ed.), Yale University Press in Association with the Royal Anthropological Institute, London, New Haven.

2011, Photography and Anthropology, Reaktion, London.

Pinney, Christopher and Nicolas Peterson (eds) 2003, Photography's Other Histories, Duke University Press, Durham.

Poignant, Roslyn 1992, 'Surveying the field of view: The making of the RAI photographic collection', in Anthropology and Photography 1860-1920, Elizabeth Edwards (ed.), Yale University Press in association with The Royal Anthropological Institute, London, New Haven: 42-73.

2004, Professional Savages: Captive Lives and Western Spectacle, University of New South Wales Press, Sydney.

Reece, Bob 1987, 'Inventing Aborigines', Aboriginal History 11: 14-23.

2007, Daisy Bates: Grand Dame of the Desert, National Library of Australia, Canberra.

2008, 'Killing with kindness: Daisy Bates and New Norcia', Aboriginal History 32: 128-145.

Reynolds, Henry 1972, Aborigines and Settlers: The Australian Experience, 1788 1939, Problems in Australian History, Cassell Australia, North Melbourne, Vic.

-1982, The Other Side of the Frontier: Aboriginal Resistance to the European Invasion of Australia, Penguin, Ringwood.

Ritchie, O. 1899a, 'The black north: Modes of nigger flogging', The Sunday Times, 3 September 1899. 
-1899b, 'Very summary justice', The West Australian Sunday Times, 3 September 1899: 3.

Royal Society of Tasmania (ed.) 1898, 'Papers and Proceedings 1897', Davies Brothers Ltd, Hobart.

Salter, Elizabeth 1971, Daisy Bates 'the Great White Queen of the Never Never', Halstead Press, Sydney.

Stingemore, Jade L. 2010, 'Surviving the "Cure": Life on Bernier and Dorre Islands under the Lock Hospital Regime', PhD thesis, University of Western Australia, Perth.

Turnbull, Paul 2008, 'British anthropological thought in colonial practice: The appropriation of Indigenous Australian bodies', in Foreign Bodies: Oceania and the Science of Race 1750-1940, Bronwen Douglas and Chris Ballard (eds), ANU E Press, Canberra: 205-228.

Tylor, E. B. 1894, 'On the Tasmanians as representatives of Paleolithic man', The Journal of The Anthropological Institute of Great Britain and Ireland 23: 141-152.

- 1900, 'On stone implements from Tasmania: Extracts from a letter by J. Paxton Moir. Communicated by Professor E. B. Tylor F.R.S.', Anthropological Institute of Great Britain and Ireland: 30-31.

Walsh, Harry B. 1892, 'The native question', The West Australian, 2 April 1892: 2.

Walsh, Julitha 1950, 'Memories of Mt Gould and the black outlaw', The Western Mail, 14 December 1950: 14.

Wills-Johnson, Brian 2014, An unexamined atrocity: The Bendu station killings', published electronically 2015, www.academia.edu/. 
This text is taken from Aboriginal History, Volume 39, 2015, edited by Liz Conor, published 2015 by ANU Press,

The Australian National University, Canberra, Australia. 